\title{
AUSTRALIJSKO-CHIŃSKI HANDEL TOWAROWY W KONTEKŚCIE RCEP I WOJNY HANDLOWEJ - DIAGNOZA I PERSPEKTYWY ROZWOJU
}

\section{Wprowadzenie}

Australijsko-chińskie relacje handlowe stały się przedmiotem szczególnego zainteresowania w 2020 r. Rok ten, który zapisał się w historii jako wyjątkowy ze względu na ogłoszenie pandemii COVID-19 oraz związane z tym skutki determinujące rozwój gospodarek wszystkich krajów świata, nieprzypadkowo przyniósł również pogorszenie relacji handlowych między Chinami a Australią. Ze względu na dociekanie prawdy o przyczynach pandemii Australia została stroną wojny handlowej, mimo że do tego czasu była przykładem kraju utrzymującego wzorowe relacje gospodarcze z ChRL, a jednocześnie pozostającego sojusznikiem USA. Lista „14 pretensji”, wystosowana przez Chiny wobec Australii zaledwie kilka dni po podpisaniu największego porozumienia handlowego świata - RCEP (ang. Regional Comprehensive Economic Partnership, pol. Regionalne Kompleksowe Partnerstwo Gospodarcze), wywarła wpływ na handel obu krajów. Na tle pokazowego ukarania Australii za dociekanie prawdy nasuwają się pytania. Czy polityczny konflikt przełoży się na długookresowe relacje handlowe pomiędzy analizowanymi krajami? Dla którego z nich konflikt będzie bardziej dotkliwy?

Głównym celem niniejszego artykułu jest diagnoza i ocena australijsko-chińskich relacji handlowych w kontekście konsekwencji i perspektyw ich rozwoju w przyszłości ze szczególnym uwzględnieniem znaczenia RCEP. Uwagę skupiono przede wszystkim na handlu towarowym. W kontekście prowadzonych analiz można postawić tezę, że polityczny konflikt między Chinami a Australią przekłada się na wzajemne relacje handlowe, których konsekwencje odczuwają obie strony, a mimo to w najbliższych latach Chiny pozostaną nadal dla Australii najważniejszym partnerem handlowym. Ważną częścią opracowania jest analiza relacji handlowych między oboma krajami, określająca perspektywy rozwoju stosunków bilateralnych będących

* ORCID: 0000-0002-7850-9101, DOI: 10.4467/23538724GS.21.001.14833

** ORCID: 0000-0002-0596-009X, DOI: 10.4467/23538724GS.21.001.14833 
skutkiem wojny handlowej. W artykule zastosowano metodę badań opisowych i wyjaśniających, przede wszystkim analizę danych i analizę przyczynowo-skutkową. Zastosowano metodę badawczą w postaci obserwacji oraz desk research.

\section{Tło australijsko-chińskich relacji handlowych}

Pierwsze relacje Australii z Chinami są datowane na lata 70. XX w. Australia nawiazała oficjalne stosunki dyplomatyczne z Chinami w roku 1972, nabrały one jednak znaczenia dopiero dekadę później, gdy Australia stała się dla Chin pomocna w zakresie nawiązywania kontaktów gospodarczych z najbardziej znaczącymi państwami na świecie. Na początku lat 70. XX w. wartość australijskiego eksportu do Chin wynosiła $63 \mathrm{mln}$ AUD, po 10 latach wzrosła do $555 \mathrm{mln}$ AUD, natomiast w $1986 \mathrm{r}$. wyniosła 1,6 mld AUD. Na początku lat 80 . XX w. efektem modernizacji chińskiego sektora przemysłowego był wzrost bilateralnego handlu między Chinami a Australia. Chiny zgłaszały zapotrzebowanie na australijskie surowce, przede wszystkim rudy metali, ale również na pszenicę i wełnę ${ }^{1}$.

W połowie lat $80 . \mathrm{XX}$ w. Chiny stanowiły dla Australii piąty największy rynek eksportowy - po Japonii, Stanach Zjednoczonych, Nowej Zelandii i Korei Południowej. Działalność polityków australijskich oraz bliskie relacje handlowe z Australią wpływały na poprawę chińskich kontaktów z innymi krajami, zarówno na płaszczyźnie handlowej, jak i w zakresie umocnienia pozycji strategicznej Chin na świecie, przynosząc Państwu Środka bezpieczeństwo i stabilność. W tym czasie wyraźnie ociepliły się kontakty polityczne i relacje chińsko-amerykańskie. Wiele zmian w Chinach dokonało się na skutek działań polityków australijskich², którzy zachęcali do nawiązywania kontaktów gospodarczych z Chinami, prowadzenia rozmów dotyczących kwestii politycznych, ale jednocześnie zalecali zachowanie ostrożności w kontaktach z Państwem Środka. Tak było na przykład po wydarzeniach 4 czerwca 1989 r. na placu Tiananmen w Pekinie ${ }^{3}$, kiedy to kontakty i rozmowy Australii z Chinami nie ustały, chociaż toczyły się na niższym szczeblu ${ }^{4}$.

1 H. Hughes, Australian Exports: Performance, Obstacles and Issues of Assistance, Report of the Committee for Review of Export Market Development Assistance, Hughes Report, Australian Government Publishing Service, Canberra 1989, s. 25, cyt. za: M. Sprengel, Znaczenie politycznych i gospodarcsych relacij Australii ₹.Japoniq i Chinami w latach 1970-2000, „Krakowskie Studia Międzynarodowe” 2009, t. 6, nr 1.

2 Należeli do nich przede wszystkim premierzy Australii: Gough Whitlam, Malcolm Fraser, Bob Hawke, Gary Woodard oraz australijscy ambasadorzy w Chinach - Gary Woodard i Stephen FitzGerald.

3 L. Gadzała, Tiananmen: Ile wydarzenia z. 1989 r. dziś znaczq dla Chin?, 4.06.2020, https://www. euractiv.pl/section/demokracja/news/tiananmen-ile-wydarzenia-1989-chiny-pekin-4-czerwca-deng-xi-jinping/ (dostęp: 22.07.2021).

4 M. Sprengel, Znaczenie politycznych i gospodarcsych relacii... 
W latach 90. XX w., kiedy chińska gospodarka wzmocniła się, odnotowany został z kolei deficyt we wzajemnej wymianie handlowej obu krajów. Powodem była protekcjonistyczna polityka handlowa Chin. Dążąc do liberalizacji handlu, Australia rozpoczęła działania mające na celu przyjęcie Państwa Środka do WTO. Stosunki handlowe między oboma krajami, w czasach rosnącej potęgi militarnej Chin oraz następującego po nim złagodzenia ich wrogiego stosunku do świata, funkcjonowały na zasadzie uzupełniania się - Chiny dysponowały tanią siła robocza, natomiast Australia posiadała surowce 5 . Wkrótce współpraca objęła również usługi edukacyjne - w 2000 r. do szkół wyższych w Australii przyjęto 20 tys. chińskich studentów ${ }^{6}$.

W 2009 r. podpisano największy w dziejach australijskiej gospodarki kontrakt o całkowitej wartości $50 \mathrm{mld}$ AUD. Obejmował on trzy koncerny energetyczne (Chevron, ExxonMobil i Shell). Kontrakt dotyczył wybudowania w stanie Australia Zachodnia instalacji do wydobywania, skraplania i magazynowania gazu ziemnego, przy czym większość tego surowca przeznaczona była na eksport do Chin. Umowa ze stroną chińską została zawarta na $20 \mathrm{lat}^{7}$.

Premier Australii Julia Gillard i prezydent Chin Xi Jinping 5 kwietnia 2013 r. w Pekinie podpisali porozumienie o wzajemnym strategicznym partnerstwie (ang. China-Australia Free Trade Agreement, ChAFTA), co spowodowało jeszcze silniejsze uzależnienie australijskiej gospodarki od Państwa Środka. W tym samym roku oba kraje podpisały umowę walutowa, w wyniku której wprowadzono pełną wymienialność australijskiego dolara na chińskiego juana, pozwalając tym samym na odejście od rozliczeń w dolarze amerykańskim ${ }^{8}$. W 2017 r. władze Australii, które do tej pory zdawały się nie dostrzegać chińskiego militaryzmu, doszły do wniosku, że nie można zaniedbywać bezpieczeństwa państwa kosztem rozwoju gospodarczego, i na odwrót ${ }^{9}$. Australia to aktywne dyplomatycznie średnie mocarstwo, zaangażowane w regionie Azji i Pacyfiku, w tym na kontynencie azjatyckim. Chiny natomiast to wielkie mocarstwo, jego interesy zlokalizowane sa przede wszystkim w Azji, ale rozciagają się na cały glob, przy czym rywalizuje w regionie Azji i Pacyfiku ze Stanami Zjednoczonymi, prowadząc zarazem poważne spory terytorialne ze swoimi sąsiadami ${ }^{10}$. Chiny sąsiadują z czternastoma państwami. W tym aspekcie położenie

\footnotetext{
5 Ibidem.

${ }^{6}$ Ł. Jureńczyk, Australijsko-chińskie stosunki gospodarcze w drugiej dekadzie XXI wieku a bezpieczeństwo ekonomiczne Australii, „Rocznik Bezpieczeństwa Międzynarodowego” 2019, t. 13, nr 1, s. 53.

7 J. Błaszczak, Stosunki australijsko-chińskie na przestrzeni XX wieku i wspótczésnie [w:] Chiny w stosunkach mięzyynarodowych, red. M. Pietrasiak, D. Mierzejewski, Lódź - Kurowice 2012, s. 166.

8 L. Jureńczyk, Australijsko-chińskie stosunki gospodarcze..., s. 53.

9 D. Zdziech, QUAD-Australia. Nowe otwarcie, „Krakowskie Studia Międzynarodowe” 2018, nr 4, s. 224.

10 L. Jureńczyk, Polityka bezpieczeństwa i obrony Australii w drugiej dekadzie XXI wieku wobec wrrostu potegi Chin, „Sprawy Międzynarodowe” 2019, t. 72, nr 3, s. 224-225.
} 
geograficzne Australii należy uznać za korzystniejsze, jednak kraj ten na pewno nie jest „samotną wyspa”, co chyba najtrafniej ujął australijski premier Robert Menzies w przemówieniu radiowym z 1939 r.: „To, co dla Europejczyków jest Dalekim Wschodem, dla nas jest Bliską Północą"11.

W wiek XXI gospodarka chińska weszła jako najszybciej rozwijający się kraj na świecie, ze wzrostem PKB ponad trzykrotnie wyższym niż Australia. Jeżeli te tendencje się utrzymają, to poziom zamożności obywateli w obu państwach będzie się sukcesywnie wyrównywał ${ }^{12}$.

W 2020 r., gdy wydawało się, że nic nie zburzy wzajemnych relacji handlowych, pojawiła się pandemia COVID-19 ${ }^{13}$. Zakłóciło to dynamiczny rozwój handlu między Australią a Chinami, których interesy ekonomiczne, a przede wszystkim polityczne okazały się rozbieżne ${ }^{14}$.

\section{Potencjał gospodarczy Chin i Australii}

Począwszy od przyjętej przez Chiny w 1978 r. polityki otwartych drzwi, gospodarka ChRL rozwijała się ze zróżnicowaną dynamiką przyrostu PKB, przy czym najniższy wynik zanotowano w 1990 r. $(3,8 \%)$, natomiast najwyższy w 1984 r. $(15,2 \%)^{15}$. Średnia dynamika wzrostu w latach 1979-2019 była wysoka i wynosiła 7\%. W $2020 \mathrm{r}$. dynamika realna PKB $(\%, r / r)$ wyniosła $2,3 \%$, zaś prognozy na 2021 rok wskazuja na wzrost $8,4 \%$. Chińska gospodarka należała do nielicznych, które uniknęły spadku PKB w 2020 r. Dla porównania w Australii dynamika PKB spadła do -2,4\%, a prognoza na 2021 rok wynosi $4,5 \% \mathrm{PKB}^{16}$.

Australia, której powierzchnia całkowita obejmuje $7,7 \mathrm{mln} \mathrm{km}^{2}$, a liczba ludności (25 mln) jest największa w Oceanii, cechuje się niską gęstością zaludnienia $\left(3,2 \text { osoby } / \mathrm{km}^{2}\right)^{17}$. Ponad połowa Australijczyków (57\%) mieszka w pięciu miastach: Sydney (5 mln), Melbourne (4,6 mln), Brisbane $(2,3 \mathrm{mln})$, Perth $(2 \mathrm{mln})$,

11 J. Błaszczak, Stosunki australijsko-chinskie..., s. 157.

12 Ł. Jureńczyk, Polityka bezpieczeństwa..., s. 224.

13 Pandemia koronawirusa czarnym labedziem, 22.04.2020, https://www.obserwatorfinansowy.pl/forma/warto-wiedziec/raporty/pandemia-koronawirusa-czarnym-labedziem/ (dostęp: 22.07.2021).

14 L. Ślazyk, Chiny-Australia - międyy pycha a desperacja. Polityka ketóci sie z biznesem, Podróż bez Paszportu, https://www.youtube.com/watch?v=_WlGR_ZPNm8 (dostęp: 22.07.2021).

15 K. Żukrowska, Chiny: potencjat (gospodarçy, polityczny i militarny) jako instrument ksztattowania nowego układu międrynarodowego, „Krakowskie Studia Międzynarodowe” 2018, nr 1.

16 Australia. Analiza miedzynarodowa, Biuro Strategii i Analiz Międzynarodowych PKO Bank Polski SA, 18.08.2020, https://wspieramyeksport.pl/api/public/files/1964/Australia_Analiza_ Miedzynarodowa_2020_08.pdf (dostęp: 22.07.2021).

17 Ludność i gospodarka Australii, 1.07.2019, http://geografia24.pl/ludnosc-i-gospodarka-australii/ (dostęp: 22.07.2021). 
Adelajda $(1,3 \mathrm{mln})^{18}$. Kraj ten należy do najlepiej rozwiniętych gospodarek świata z PKB całkowitym wynoszącym w 2020 r. 1359 mld USD, czyli PKB per capita PPP ${ }^{19}$ równym $51680 \mathrm{USD}^{20}$. Jego głównymi zasobami naturalnymi są: tlenek glinu, węgiel, ruda żelaza, miedź, cyna, złoto, srebro, uran, nikiel, wolfram, pierwiastki ziem rzadkich, piaski mineralne, ołów, cynk, diamenty, gaz ziemny, ropa naftowa. Poza tym Australia jest największym na świecie eksporterem netto węgla, odpowiadając za $29 \%$ światowego eksportu tego surowca ${ }^{21}$.

Chiny są największym pod względem powierzchni krajem, który w całości leży w Azji. Jest to jednocześnie najludniejszy kraj świata, chociaż Indie powoli zbliżaja się do pierwszego miejsca pod tym względem. Prognozy wskazują że stosowana przez lata polityka jednego dziecka daje efekty w postaci gwałtownego przyspieszenia starzenia się społeczeństwa, co będzie skutkować piętrzacymi się trudnościami dla chińskiego systemu gospodarczego i emerytalnego ${ }^{22}$. Chiny zajmuja powierzchnię całkowita 9,6 mln $\mathrm{km}^{2}$, a liczba ludności wynosi 1,4 mld. Średnia gęstość zaludnienia to 156 osób $/ \mathrm{km}^{2}$, przy czym 95\% ogółu ludności zamieszkuje wschodnią część kraju, gdzie gęstość zaludnienia utrzymuje się na poziomie średnio 800 osób na $1 \mathrm{~km}^{2}$. Chiny należą do gospodarek szybko rozwijających się, z PKB całkowitym wynoszącym w 2020 r. 14722 mld USD, czyli PKB per capita PPP osiagnął wartość 17192 USD $^{23}$. W strukturze PKB Chin udział usług stanowi $53 \%$, natomiast $39 \%$ przypada na przemys ${ }^{24}$. W strukturze PKB Australii udziały te wynoszą odpowiednio $70 \%$ i $26 \%{ }^{25}$. Do zasobów naturalnych Chin zalicza się m.in.: węgiel, rudę żelaza, hel, ropę naftową, gaz ziemny, pierwiastki ziem rzadkich. Ponadto Państwo Środka cechuje się największym na świecie potencjałem hydroenergetycznym ${ }^{26}$.

W kontekście powyższych danych należy dodać, że społeczeństwo australijskie również się starzeje. Prognozy Organizacji Narodów Zjednoczonych zakładaja zwiększenie mediany wieku w 2050 r. - w Chinach $^{27}$ do 47,6 lat z 36,7 lat w 2015 r.,

\footnotetext{
18 Australia. Przewodnik po rynku, Warszawa 2018, s. 7.

19 PPP - parytet siły nabywczej.

20 Australia. Analiza...

21 Australia, The World Factbook, https://www.cia.gov/the-world-factbook/countries/australia/ (dostęp: 22.07.2021).

22 P. Paszak, Chiny starzeja sie w btyskawicznym tempie, 26.11.2020, https://warsawinstitute.org/pl/ chiny-starzeja-sie-w-blyskawicznym-tempie/ (dostęp: 22.07.2021).

23 Chiny. Analiza międzynarodowa, Biuro Strategii i Analiz Międzynarodowych PKO Bank Polski SA, 24.06.2020, https://wspieramyeksport.pl/api/public/files/1927/Chiny_Analiza_Miedzynarodowa_2020_06.pdf (dostęp: 22.07.2021).

24 Ibidem.

25 Australia. Analiza...

26 China, The World Factbook, https://www.cia.gov/the-world-factbook/countries/china/ (dostęp: 22.07.2021).

27 Chiny. Analiza...
} 
a w Australiii ${ }^{28}$ do 41,8 lat z 37,2 lat w 2015 r. Demografia stanowi kluczowy czynnik determinujący rozwój społeczno-gospodarczy. Dodatkowo oczekiwana długość życia w Australii wynosi 83 lata, natomiast w Chinach 77 lat ${ }^{29}$. W związku z tymi danymi warto porównać kształtowanie się wskaźnika HDI (ang. Human Development Index) w obu krajach. W odróżnieniu od PKB, HDI zwraca uwagę na zmiany jakościowe. Jest to wskaźnik rozwoju społecznego, umożliwiający ocenienie jakości życia w danym kraju z punktu widzenia opieki zdrowotnej, edukacji oraz zarobków jego obywateli. Przyjmuje on wartość od 0 do 1, przy czym im wyższy jest jego poziom, tym lepszą oznacza jakość życia pod względem wskazanych kryteriów, które wyrażone są w parytecie siły nabywczej ${ }^{30}$. Na tej podstawie każdy kraj jest zaliczany do jednej z czterech grup w zależności od stopnia rozwoju społeczno-ekonomicznego: bardzo wysoki poziom rozwoju, wysoki poziom rozwoju, średni poziom rozwoju oraz niski poziom rozwoju ${ }^{31}$. Australia, która zajęła 8. miejsce w rankingu HDI w 2019 r., zalicza się do pierwszej grupy krajów $\left(\mathrm{HDI}_{\text {Australia }}=0,944\right)$. Natomiast Chiny, obejmując 85. pozycję, zaklasyfikowane są do grupy krajów o wysokim poziomie rozwoju $\left(\mathrm{HDI}_{\text {Chiny }}=0,761\right)^{32}$.

W aspekcie udziału w międzynarodowym handlu towarowym Chiny są największym eksporterem świata: z wartością 2499 mld USD w 2019 r. posiadają 13,2\% udziału w handlu światowym. Na drugim miejscu znajdują się Stany Zjednoczone z udziałem 8,7\%, a na trzecim Niemcy (7,9\%). Udział Australii w handlu światowym wynosi tyle samo co udział Polski, czyli 1,4\%. Z punktu widzenia największych importerów towarowych Chiny zajmują drugie miejsce na świecie z udziałem 10,8\%, co odpowiada wartości 2077 mld USD. Pierwsze miejsce wśród największych światowych importerów zajmują Stany Zjednoczone (2568 mld USD, czyli udział 13,4\% w towarowym imporcie światowym), natomiast trzecie miejsce przypada Niemcom (udział 6,4\%). Udział Australii w światowym imporcie towarowym jest nieco mniejszy niż udział Polski i wynosi 1,2\%. Biorąc pod uwagé światowy handel usługowy - który wprawdzie nie stanowi przedmiotu bezpośredniej analizy w niniejszym opracowaniu, ale trudno o nim nie wspomnieć w aspekcie relacji australijsko-chińskich - udział Chin w 2019 r. wyniósł 4,6\%, co odpowiada wartości 282 mld USD. Do liderów w tym obszarze należą Stany Zjednoczone (14,1\% udziału w światowym eksporcie usług, czyli 853 mld USD), Wielka Brytania (6,8\%) i Niemcy (5,5\%).

\footnotetext{
28 Australia. Analiza...

29 Data for China, The World Bank, www.data.worldbank.org (dostęp: 22.07.2021).

$30 \mathrm{Na}$ pierwszym miejscu w 2019 r. była Norwegia $\left(\mathrm{HDI}_{\text {Norwegia }}=0,957\right)$, następnie ex aequo Irlandia i Szwajcaria $\left(\mathrm{HDI}_{\text {Irlandia }}=\mathrm{HDI}_{\text {Szwajcaria }}=0,955\right)$, na trzecim miejscu Hongkong, Chiny, SAR $\left(\mathrm{HDI}_{\text {Hongkong }}=0,949\right)$; zob. Human Development Report 2020: The next frontier Human development and the Anthropocene, New York 2020, s. 343.

31 S. Pangsy-Kania, Ksztattowanie sie wską́nika HDI w Chinach w latach 1980-2013 na tle pozostatych krajón BRICS, „Gdańskie Studia Azji Wschodniej” 2015, z. 8.

32 Human Development Report 2020...
} 
Udział Australii jest o 0,1 punktu procentowego niższy niż udział Polski i wynosi $1,1 \%$, co odpowiada wartości 69 mld USD. W imporcie usług pierwsze miejsce przypada Stanom Zjednoczonym (9,8\% udziału w światowym imporcie usług, czyli 564 mld USD), na drugim miejscu są Chiny (8,7\% udziału i wartość 497 mld USD), a na trzecim Niemcy (6,3\% udziału, czyli 363 mld USD). Australia jest na miejscu 23. z udziałem zbliżonym do udziału w eksporcie usług $(1,2 \%$, co odpowiada wartości 70 mld USD) $)^{33}$.

Ten krótki przegląd danych, zwracający szczególną uwagę na „podium handlu międzynarodowego", wskazuje na ogromne znaczenie Chin w gospodarce światowej $^{34}$. Dodatkowo w ostatnim kwartale 2020 r., czyli w roku ogłoszenia pandemii COVID-19, chiński eksport wzrósł o 17\%, licząc rok do roku, podczas gdy cały globalny handel wzrósł w tym czasie jedynie o ok. 5\%. Wzrost dotowanego przez rządy światowego popytu na produkty, np. sprzęt AGD/RTV, wspomagał chińską produkcję, jednak ważnym źródłem wzrostu gospodarczego w Chinach były też ogromne, a zarazem niskowydajne inwestycje budowlane - zarówno mieszkaniowe, jak i infrastrukturalne ${ }^{35}$. W tabeli 1 przedstawiono dane dotyczące znaczenia handlu międzynarodowego w gospodarce Chin i Australii w ostatnich 15 latach, przy czym szczególną uwagę zwrócono na bilans handlowy w handlu towarowym $\mathrm{i}$ usługowym obu analizowanych krajów.

Jak wynika $\mathrm{z}$ danych zawartych $\mathrm{w}$ tabeli 1 , dodatni bilans handlowy $\mathrm{w}$ analizowanym okresie charakteryzował się tendencją rosnącą, natomiast w odniesieniu do handlu usługowego obserwowany był rosnący deficyt. Australia w 2019 r. zanotowała nadwyżkę w handlu towarowym, chociaż jeszcze 4 lata temu deficyt wyniósł ponad 20 mld USD, zaś w handlu usługami zaobserwowano deficyt, który był sześciokrotnie niższy niż w 2015 r. W 2020 r. w stosunku do roku poprzedniego w Australii nastapił spadek wartości zarówno eksportu (o 9,32\%), jak i importu (o 6,3\%) w zakresie towarów ${ }^{36}$. W Chinach w tym samym czasie nastąpił natomiast niewielki wzrost eksportu (o 1,92\%) oraz spadek importu (o $2,4 \%)^{37}$.

33 World Trade Statistical Review 2020, s. 82, https://www.wto.org/english/res_e/statis_e/wts 2020_e/wts20_toc_e.htm (dostęp: 22.07.2021).

34 S. Pangsy-Kania, Od „Made in China” do „Created in China” - droga Chin do supremacii innowacyjnej, „Gdańskie Studia Azji Wschodniej” 2021, z. 19.

35 J. Frączyk, Pompowany wrrost Chin. „Te inwestycje nie prayniosa mysokiego zurotu”, 19.01.2021, https:// businessinsider.com.pl/finanse/makroekonomia/wzrost-pkb-chin-napompowany-jest-nisko-wydajnymi-inwestycjami/yh8qw8v (dostęp: 22.07.2021).

36 Australia, Directorate General for Trade, European Commission, https://webgate.ec.europa.eu/isdb_results/factsheets/country/details_australia_en.pdf (dostęp: 22.07.2021).

37 China, Directorate General for Trade, European Commission, https://webgate.ec.europa. eu/isdb_results/factsheets/country/details_china_en.pdf (dostęp: 22.07.2021). 
Tabela 1. Handel towarowy i usługowy Australii i Chin w latach 2005-2019

\begin{tabular}{|l|c|c|c|c|c|c|c|c|c|}
\hline Państwa & \multicolumn{7}{|c|}{ Australia } & \multicolumn{7}{c|}{ Chiny } \\
\hline \multicolumn{1}{|c|}{ Rok } & $\mathbf{2 0 0 5}$ & $\mathbf{2 0 1 0}$ & $\mathbf{2 0 1 5}$ & $\mathbf{2 0 1 9}$ & $\mathbf{2 0 0 5}$ & $\mathbf{2 0 1 0}$ & $\mathbf{2 0 1 5}$ & $\mathbf{2 0 1 9}$ \\
\hline \multicolumn{8}{|c|}{ Handel towarowy (mln USD) } \\
\hline Eksport & 106097 & 212634 & 187684 & 271005 & 761953 & 1577754 & 2273468 & 2499457 \\
\hline Import & 125281 & 201639 & 208501 & 221564 & 659953 & 1396247 & 1679566 & 2078386 \\
\hline $\begin{array}{l}\text { Bilans } \\
\text { handlowy }\end{array}$ & -19184 & 10995 & -20817 & 49441 & 102000 & 181507 & 593902 & 421071 \\
\hline \multicolumn{8}{|c|}{ Handel usługowy (mln USD) } \\
\hline Eksport & 32227 & 51899 & 54876 & 69975 & 78469 & 178339 & 218634 & 283192 \\
\hline Import & 33057 & 57709 & 63705 & 71531 & 83971 & 193401 & 435541 & 500680 \\
\hline $\begin{array}{l}\text { Bilans } \\
\text { handlowy }\end{array}$ & -830 & -5810 & -8829 & -1556 & -5502 & -15063 & -216907 & -217488 \\
\hline
\end{tabular}

Źródło: Opracowanie własne na podstawie General Profile: Australia, UNCTADstat, http://unctadstat.unctad.org/countryprofile/generalprofile/en-gb/036/index.html (dostęp: 22.07.2021).

W 2019 r. głównymi partnerami Australii w eksporcie towarowym były Chiny (102 966 mln USD, co odpowiada 39\% udziałowi w eksporcie ogółem), a następnie Japonia (39 $455 \mathrm{mln}$ USD), Korea Południowa (17 $464 \mathrm{mln}$ USD), Indie (15 $300 \mathrm{mln}$ USD), Wielka Brytania (10 $570 \mathrm{mln}$ USD) i Stany Zjednoczone (10 $171 \mathrm{mln}$ USD $)^{38}$. Chiny są głównym partnerem Australii w imporcie dóbr (udział 25,2\% w imporcie ogółem, co odpowiada wartości 52,7 mld USD). Kolejne miejsca zajmują: Stany Zjednoczone (11,9\%), Japonia (7,12\%), Niemcy (4,97\%) i Tajlandia $(4,8 \%)^{39}$.

W tym samym roku do pięciu głównych partnerów handlowych Chin w handlu towarowym należały: Stany Zjednoczone (418 909 mln USD, co stanowiło 16,7\% wartości całego eksportu), Hong Kong SAR (279 834 mln USD), Japonia (143 $335 \mathrm{mln}$ USD), Korea Południowa (111 $071 \mathrm{mln}$ USD) i Wietnam (98 $080 \mathrm{mln}$ USD) ${ }^{40}$. Udział Australii w eksporcie Chin wyniósł w 2019 r. jedynie 2,05\%, co stanowi wartość 52,7 mld USD. W imporcie towarowym głównymi partnerami Państwa Środka są: Korea Południowa (8,61\%), Japonia (8,14\%), Australia (7,03\%), Niemcy $(6,82 \%)$ i Stany Zjednoczone $(6,54 \%)^{41}$.

Najważniejszymi towarowymi produktami eksportowymi Australii w 2019 r. były: ruda żelaza (67,5 mld USD), brykiety węglowe (51,5 mld USD), gaz naftowy

38 General Profile: Australia, UNCTADstat, http://unctadstat.unctad.org/countryprofile/generalprofile/en-gb/036/index.html (dostęp: 22.07.2021).

39 Australia, https://oec.world/en/profile/country/aus (dostęp: 22.07.2021).

40 General Profile: China, UNCTADstat, http://unctadstat.unctad.org/countryprofile/generalprofile/en-gb/156/index.html (dostęp: 22.07.2021).

41 China, https://oec.world/en/profile/country/chn (dostęp: 22.07.2021). 
(34,1 mld USD), złoto (25,4 mld USD) i tlenek glinu (5,6 mld USD). Natomiast do najważniejszych towarów importowanych do Australii zaliczają się: rafinowana ropa naftowa (16,8 mld USD), samochody osobowe (15,8 mld USD), ropa naftowa (7,9 mld USD), sprzęt nadawczy (6,37 mld USD) i samochody dostawcze $(5,84 \text { mld USD })^{42}$. Jeżeli chodzi o grupy towarowe $z$ najszybszym wzrostem ${ }^{43}$, to w 2019 r. w odniesieniu do eksportu były to nikiel i artykuły z niklu (73\% r/r), a następnie rudy metali, żużel i popiół $(39 \%$ r/r), produkty farmaceutyczne $(34 \% \mathrm{r} / \mathrm{r})$, owoce i orzechy jadalne $(26 \% \mathrm{r} / \mathrm{r})$, mięso i podroby jadalne $(20 \% \mathrm{r} / \mathrm{r})$. W imporcie natomiast najszybszy wzrost dotyczył: statków powietrznych, statków kosmicznych i ich części (55\% r/r), różnych przetworów spożywczych (25\% r/r), nawozów (11\% r/r), przetworów ze zbóż, mąki, skrobi, mleka i pieczywa cukierniczego $(10 \% \mathrm{r} / \mathrm{r})$ oraz obuwia, getrów itp. $(8 \% \mathrm{r} / \mathrm{r})^{44}$. Po spadku dynamiki importu towarów w 2020 r. na skutek ogłoszenia pandemii COVID-19 do poziomu $-2,2 \%$ r $/ \mathrm{r}$ prognozowany jest wzrost wynoszący $9 \% \mathrm{w} 2020 \mathrm{r}^{45}$, a następnie tendencja spadkowa dynamiki importu towarów do Australii od 3,4\% w 2022 r. do 2,4\% w 2026 r. W zakresie eksportu towarów z Australii po spadku dynamiki w 2020 r. do 4,3\% r/r prognozy wskazują na trend wznoszący $6,6 \% \mathrm{w} 2021 \mathrm{r}$., a następnie trend malejący, począwszy od 3,2\% w $2022 \mathrm{r}$., a skończywszy na 1,9\% w $2026 \mathrm{r} .{ }^{46}$

Najważniejszymi produktami eksportowymi Chin w 2019 r. były: sprzęt nadawczy (208 mld USD), komputery (141 mld USD), układy scalone (108 mld USD), części do maszyn biurowych (82,7 mld USD) i telefony (54,8 mld USD). Największe produkty importowane z Chin to: ropa naftowa (204 mld USD), układy scalone (123 mld USD), ruda żelaza (83,1 mld USD), gaz naftowy (47,8 mld USD) i samochody $(43,1 \text { mld USD })^{47}$. Do grup towarowych $\mathrm{z}$ najszybszym wzrostem ${ }^{48} \mathrm{w}$ sferze eksportu w 2019 r. należały: wyroby ceramiczne $(20 \%$ r/r), papier i tektura, artykuły z masy papierniczej, papieru i tektury $(19 \% \mathrm{r} / \mathrm{r})$, zabawki, gry i artykuły sportowe $(17 \% \mathrm{r} / \mathrm{r} /)$, artykuły przemysłowe różne $(15 \% \mathrm{r} / \mathrm{r})$, włókna chemiczne ciagłe $(14 \% \mathrm{r} / \mathrm{r})$. W imporcie natomiast najszybszy wzrost dotyczyl: mięsa i podrobów jadalnych $(80 \% \mathrm{r} / \mathrm{r})$, owoców i orzechów jadalnych $(42 \% \mathrm{r} / \mathrm{r})$, ryb, skorupiaków i mięczaków ( $40 \% \mathrm{r} / \mathrm{r}$ ), olejków eterycznych i rezinoidów, preparatów perfumeryjnych, kosmetycznych i toaletowych $(38 \% \mathrm{r} / \mathrm{r})$ oraz produktów farmaceutycznych

\footnotetext{
42 Australia, https://oec.world/en/profile/country/aus (dostęp: 22.07.2021).

43 Spośród 30 grup towarów o największym udziale w eksporcie oraz 30 grup towarów o największym udziale w imporcie.

44 Australia. Analiza miedzynarodowa...

45 International Monetary Fund, World Economic Outlook. Managing divergent recoveries, [b.m.] 2021.

46 Australia. Znajdź rynki eksportowe, https://wspieramyeksport.pl/znajdz-rynki-eksportowe/ au/australia (dostęp: 22.07.2021).

47 China, https://oec.world/en/profile/country/chn (dostęp: 22.07.2021).

48 Spośród 30 grup towarów o największym udziale w eksporcie oraz 30 grup towarów o największym udziale w imporcie.
} 
$(27 \% \mathrm{r} / \mathrm{r})^{49}$. W $2020 \mathrm{r}$. nie zanotowano spadku dynamiki importu towarów do Chin wyniosła ona 4,4\% r/r. Prognozy wskazują na wzrost dynamiki importu w $2021 \mathrm{r}$. do 6,8\% r/r, a następnie tendencję spadkową od 5,5\% w 2022 r. do 4\% w 2026 r. W eksporcie towarów w 2020 r. w związku z ogłoszeniem pandemii COVID-19 również nie odnotowano spadku - dynamika wyniosła 1,9\% r/r w stosunku do 0,2\% w 2019 r. Zgodnie z prognozami MFW w 2021 r. dynamika eksportu towarów z Chin ma wynieść 9,2\% r/r, po czym ma następować trend spadkowy - od 4,2\% w 2022 r. do 3,7\% w 2026 r. $^{50}$

Z przedstawionych powyżej danych dotyczących międzynarodowego handlu towarowego wynika, że Chiny są dla Australii najważniejszym partnerem zarówno w eksporcie (udział prawie 40\%), jak i w imporcie (udział 25\%), przy czym australijski eksport do Chin obejmuje jedynie surowce. Natomiast dla Chin udział Australii w handlu towarowym ma większe znaczenie w imporcie niż w eksporcie. Od kilkunastu lat dokonuje się ponowne ekonomiczne „odkrywanie Australii” przez Państwo Środka, tak jak miało to miejsce w XIX w., choć wówczas zabroniony był wywóz surowców do Chin. Jednak podobnie jak w tamtym okresie również współcześnie mówi się o chińskim zagrożeniu, które obecnie postrzegane jest przez pryzmat bezpieczeństwa ${ }^{51}$. W tym kontekście warto zwrócić szczególną uwagę na zmiany we wzajemnym handlu obu krajów w latach 2000-2019. Należy przy tym podkreślić, że stosunki dwustronne między Australią a Chinami są wieloaspektowe i obejmują bezpieczeństwo narodowe, gospodarkę i handel oraz politykę zagraniczną i krajową ${ }^{52}$.

\section{Bilateralny handel towarowy między Australią a Chinami w latach 2000-2019}

W ostatnich latach handel dwustronny między Australią a Chinami wyraźnie wzrósł. Obecnie Chiny są największym odbiorcą australijskiego eksportu (prawie 40\%), a jednocześnie największym źródłem importu do Australii (prawie 25\%). Na rys. 1 przedstawiono powyższe dane, a także linię trendu dla importu z Chin do Australii, wskazującą na tendencję wzrostową (dodatni współczynnik przy $x$ w równaniu).

\footnotetext{
49 Chiny. Analiza...

${ }^{50}$ Chiny. Znajdź rynki eksportowe, https://wspieramyeksport.pl/znajdz-rynki-eksportowe/ cn/chin (dostęp: 22.07.2021).

51 T. Okraska, Stosunki australijsko-chinskie. Historia, stan obecny, perspektywy [w:] Australia w XX i XXI wieku. Polityka, bistoria i kultura, red. A. Kandzia-Poździał, J. Siekiera, Katowice 2017, s. 24.

52 Relacje handlowe miedzy Chinami i Australia, 19.04.2021, https://www.coface.pl/Aktualnosci-i-media/Biuro-prasowe/Relacje-handlowe-miedzy-Chinami-i-Australia (dostęp: 22.07.2021).
} 


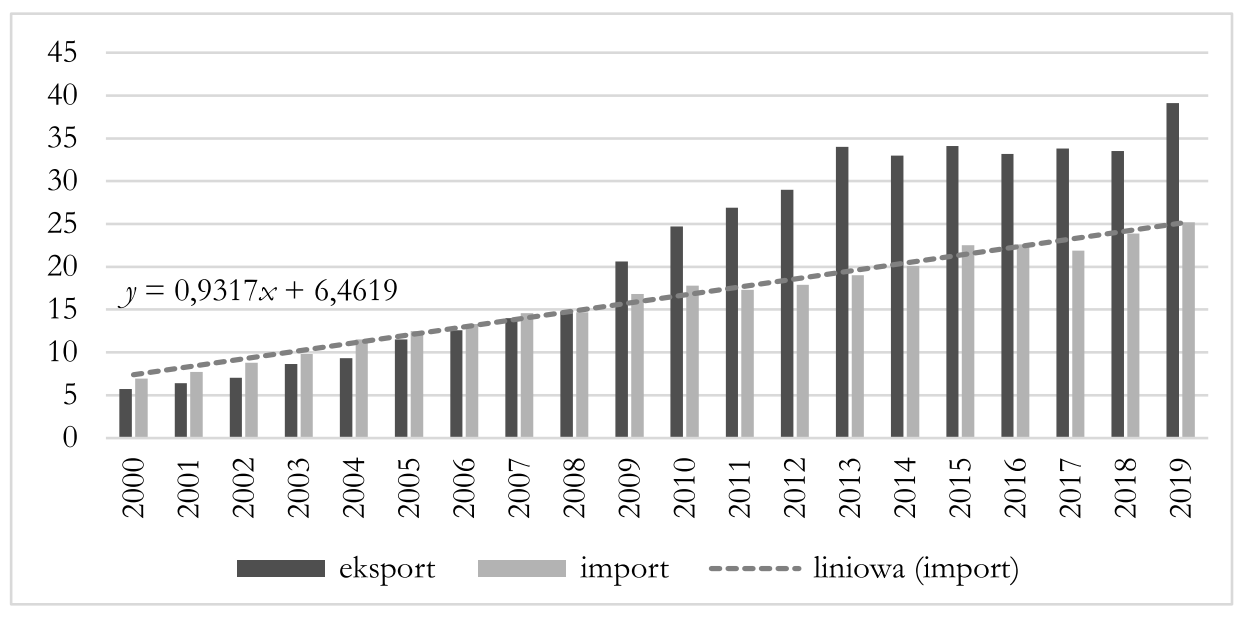

Rys. 1. Udział Chin w towarowym eksporcie i imporcie Australii (\%) oraz linia trendu dla importu

Źródło: Opracowanie własne na podstawie OEC, https://oec.world/ (dostęp: 22.07.2021).

Jak wynika z danych zawartych na rys. 1, od 2000 do 2008 r. import z Chin do Australii przewyższał eksport z Australii do Chin ${ }^{53}$. Począwszy od 2009 r., eksport zaczął wyraźnie przewyższać import, przyczyniając się do powstania deficytu w bilansie handlowym Chin z Australią. Australia należy do grupy krajów, od których Chiny więcej kupuja (importuja), niż im sprzedaja (eksportuja). Tylko Korea Południowa i Szwajcaria mają wyższy bilans handlowy z Chinami ${ }^{54}$. Większość krajów świata bowiem znacznie więcej towarów sprowadza z Państwa Środka, niż do niego eksportuje.

Udział Australii w całym imporcie towarowym Chin wynosi 7\%, podczas gdy jeszcze 20 lat temu oscylował wokół 2\%, zaś udział Australii w eksporcie Chin wyniósł w 2019 r. 2,05\% i na przestrzeni analizowanego okresu był stabilny (rys. 2).

Na rys. 3 przedstawiono wartość eksportu towarów z Chin do Australii w latach 2000-2019. W 2017 r., w porównaniu z 2000 r., wartość eksportu wzrosła dziesięciokrotnie, a w 2019 r. wyniosła 52,7 mld USD. Uzupełnieniem danych zawartych na tym wykresie jest obliczenie odchylenia standardowego, które jako klasyczna miara zmienności rozkładu pozwala stwierdzić, czy w badanej próbie jednostki są podobne ze względu na badaną cechę, czy też znacznie różnią się między sobą (rys. 4). Odchylenie standardowe zostało policzone dla każdego roku, począwszy od 2000 r. Dotyczy ono trzech głównych towarów eksportowanych z Chin do Australii. W 2005 r. było ono najwyższe $(4,81)$, co oznacza, że procentowy udział

53 Y. Sheng, L. Song, Comparative advantage and Australia-China bilateral trade, „Economic Papers” 2008, vol. 27 , no. 1.

54 Oto państwa, z ketórymi Chiny maja ujemny bilans handlowy, 25.08.2017, https://forsal.pl/artykuly/1065651,oto-panstwa-z-ktorymi-chiny-maja-ujemny-bilans-handlowy.html (dostęp: 22.07.2021). 
eksportowanych towarów był różny, czyli różnica na tle pozostałych lat była najbardziej nieproporcjonalna (udział komputerów wyniósł 10,8\%, garniturów damskich $2,48 \%$, wyświetlaczy wideo 2,43\%). W $2000 \mathrm{r}$. odchylenie standardowe dla zbioru najważniejszych towarów eksportowanych z Chin do Australii było najmniejsze i wyniosło 0,82 (komputery 4,51\%, niedziane garnitury damskie 3,31\%, niedziane garnitury męskie 2,94\%), zaś w 2019 r. osiagnęło 1,65, co znaczy, że udział procentowy poszczególnych towarów zaczął się wyrównywać (sprzęt nadawczy 7,29\%, komputery $7,27 \%$, rafinowana ropa naftowa $4,42 \%$ ).

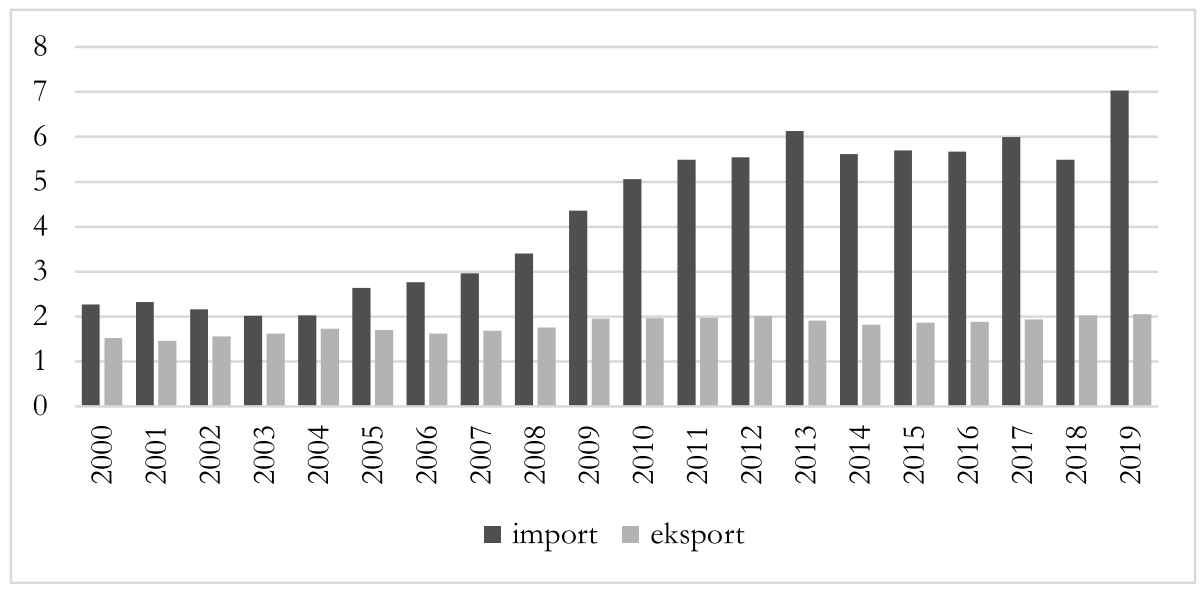

Rys. 2. Udział Australii w towarowym imporcie i eksporcie Chin (\%)

Źródło: Opracowanie własne na podstawie OEC, https://oec.world/ (dostęp: 22.07.2021).

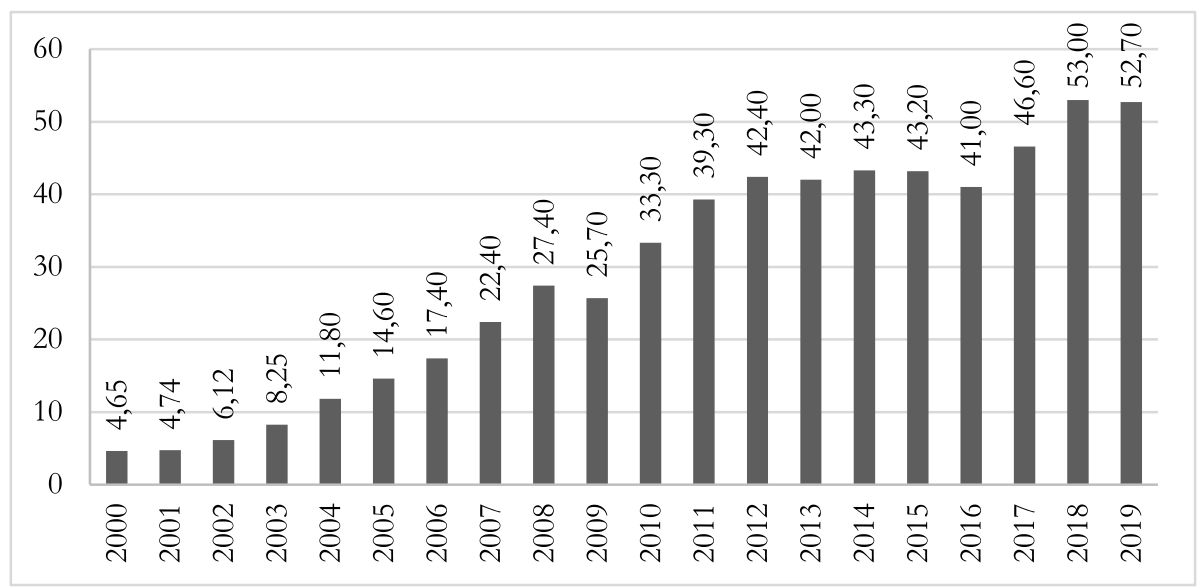

Rys. 3. Eksport z Chin do Australii (mld USD)

Źródło: Opracowanie własne na podstawie OEC, https://oec.world/ (dostęp: 22.07.2021). 


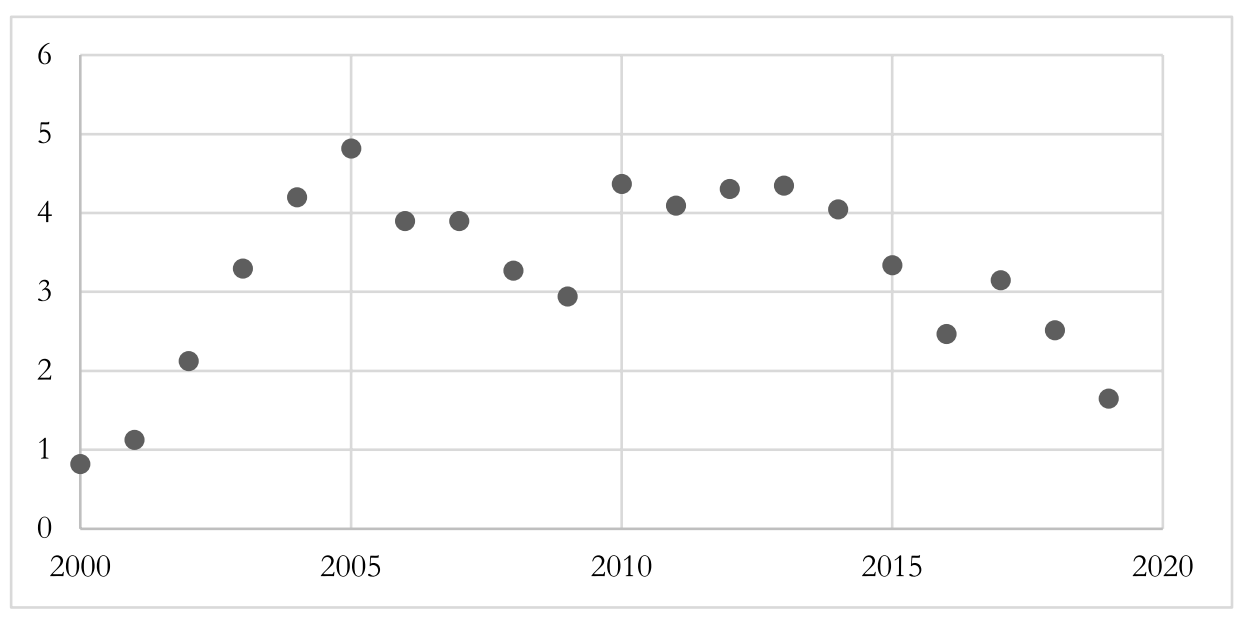

Rys. 4. Odchylenie standardowe dotyczące najważniejszych towarów eksportowanych z Chin do Australii w latach 2000-2019

Źródło: Opracowanie własne na podstawie OEC, https://oec.world/ (dostęp: 22.07.2021).

Znając odchylenie standardowe (rys. 4), można obliczyć współczynnik zmienności $V$, który stanowi iloraz odchylenia standardowego i średniej arytmetycznej pomnożonej przez $100 \%$. Jest on miarą rozproszenia informującą o zróżnicowaniu. Jeśli współczynnik zmienności waha się w przedziale $0-20 \%$, znaczy to, że zróżnicowanie populacji jest małe. W zakresie eksportu z Chin do Australii współczynnik zmienności osiagnął największą wartość w roku 2005 (15\%), najniższą zaś w roku $2000(2,8 \%)$. W 2019 r. $V$ wyniósł 5,7\%. Reasumując, w całym analizowanym okresie zróżnicowanie było małe.

Z kolei eksport z Australii do Chin w latach 2000-2019 charakteryzowal się dużą dynamiką - w 2000 r. wynosił 3,7 mld USD, a w 2019 r. 111 mld USD (rys. 5). Znalazło to wyraz w odchyleniu standardowym (rys. 6), które wskazuje, ile średnio odchylają się wartości badanej cechy od średniej arytmetycznej. Odchylenie standardowe zostało policzone dla każdego roku, począwszy od 2000 r. Dotyczy ono trzech głównych towarów eksportowanych z Australii do Chin. W roku 2011 okazało się ono najwyższe $(32,26)$, co znaczy, że procentowy udział eksportowanych towarów różnił się między sobą najbardziej, czyli różnica na tle pozostałych lat była najbardziej nieproporcjonalna (ruda żelaza $61,2 \%$, brykiety węglowe 6,63\%, ropa naftowa 4,09\%). W 2000 r. odchylenie standardowe dla zbioru najważniejszych towarów eksportowanych z Australii do Chin wskazywało najmniejsze wartości i wyniosło 1,86 (ruda żelaza 16,7\%, wełna 14,5\%, tlenek glinu 13\%), zaś w 2019 r. osiagnęło poziom 23,1, wskazując, że udział procentowy poszczególnych towarów jest bardziej rozproszony niż na początku badanego okresu (ruda żelaza 49,7\%, gaz naftowy $10,7 \%$, złoto $8,64 \%$ ). 


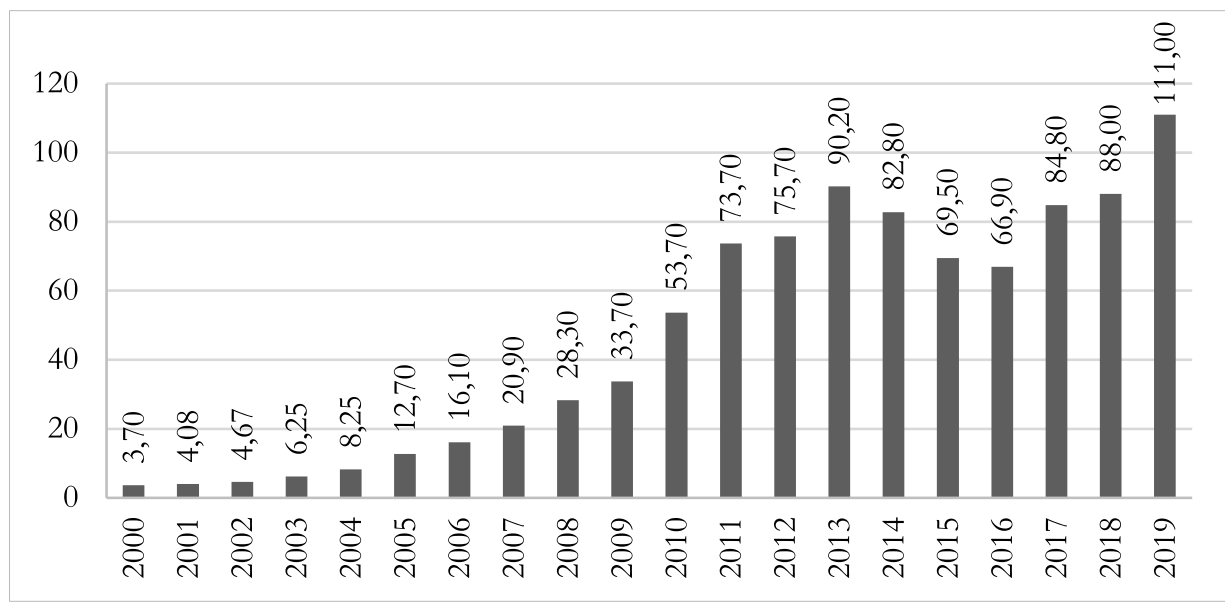

Rys. 5. Eksport z Australii do Chin (mld USD)

Źródło: Opracowanie własne na podstawie OEC, https://oec.world/ (dostęp: 22.07.2021).

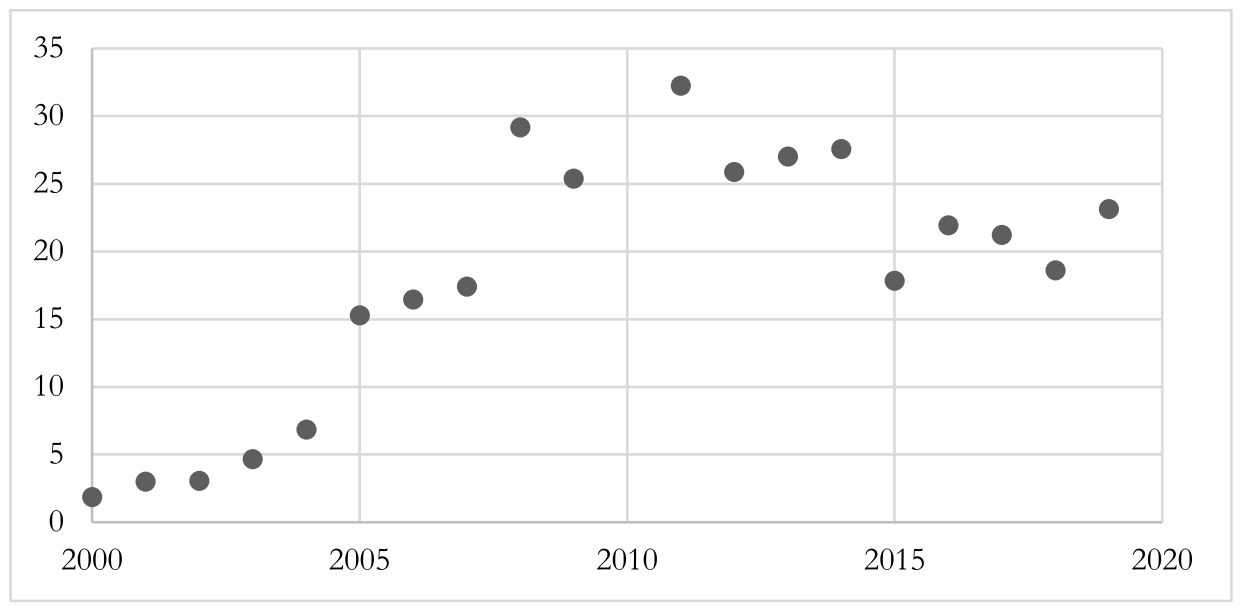

Rys. 6. Odchylenie standardowe dotyczące najważniejszych towarów eksportowanych z Australii do Chin w latach 2000-2019

Źródło: Opracowanie własne na podstawie OEC, https://oec.world/ (dostęp: 22.07.2021).

Jeśli współczynnik zmienności znajduje się w przedziale 40-60\%, mówimy o dużym zróżnicowaniu, jeśli przekroczy 60\%, znaczy to, że zróżnicowanie jest bardzo duże. Tak jest w wypadku eksportu towarowego z Australii do Chin. W 2000 r. współczynnik zmienności wynosił 4\%, 10 lat później 69\%, a w 2019 r. - 49,5\%.

Z punktu widzenia udziału poszczególnych towarów w handlu międzynarodowym najważniejszym towarem importowanym z Chin do Australii od 2000 r. sa 
komputery (rys. 7) - poza rokiem 2017 i 2019, gdy pierwsze miejsce zajmował sprzęt nadawczy, stanowiąc $7,9 \%$ (2017 r.) i 7,29\% (2019 r.) (rys. 10, 11). Drugim towarem importowanym z Chin na początku wieku byly garnitury damskie (ok. 3\% udziału w chińskim eksporcie), a począwszy od 2006 r. sprzęt nadawczy i komputery. W wypadku towaru, który z punktu widzenia udziału w chińskim eksporcie do Australii zajmuje trzecie miejsce, obserwujemy większe zróżnicowanie. W $2000 \mathrm{r}$. były to garnitury męskie z udziałem 3\%, natomiast w $2003 \mathrm{r}$. ich znaczenie spadło do $2 \%$. W 2004 r. na trzecim miejscu pojawił się sprzęt nadawczy $(2,4 \%)$, w latach 2005-2009 wyświetlacze wideo, w latach 2010-2011 urządzenia półprzewodnikowe (udział kolejno 2,39\% i 2,96\%), w latach 2012-2016 telefony (z udziałem od 2,33\% do 3,38\%), w 2017 r. - części do maszyn biurowych, zaś w kolejnych latach rafinowana ropa naftowa $(4,42 \% \mathrm{w} 2019 \mathrm{r}$.).

Jeśli chodzi o towary eksportowe z Australii do Chin, to największy udział procentowy w całym analizowanym okresie miała ruda żelaza (rys. 8). W 2000 r. udział ten wyniósł ok. $17 \%$ w całości eksportu z Australii do Chin, dekadę później - ok. 50\%, a w 2011 r. ponad 60\%. W 2019 r. udział rudy żelaza nadal był wysoki i wynosił 49,7\%. Zarówno drugie, jak i trzecie miejsce w eksporcie z Australii do Chin zajmuja surowce. Drugim towarem w latach 2000-2002 była wełna z udziałem 14,5\% w 2000 r. i 15,1\% w 2002 r. Począwszy od 2003 r., na drugim miejscu był tlenek glinu (14,7\%). Eksport tego surowca spadał do 2008 r. (4,83\%) i w 2009 r. jego miejsce zajęły brykiety węglowe, których udział w 2014 r. wyniósł 9,61\%. W latach 2015-2017 na drugim miejscu znalazło się złoto $(21,7 \%$ w 2015 r., w 2017 r. - 10,8\%). W 2018 r. ponownie drugie miejsce należało do brykietów węglowych (12\%), natomiast w 2019 r. do gazu naftowego (10,7\%). Trzecim towarem w latach 2000-2002 pozostawał tlenek glinu z udziałem od 13\% do 11,5\%, a w latach 2003-2008 wełna, przy czym jej najwyższy udział w eksporcie do Chin przypadł na 2004 r. (11\%). W kolejnych latach na trzecim miejscu znajdowały się: ropa naftowa (do 2011 r.), złoto (lata 2012-2014, ok. 8\%), brykiety weglowe (w latach 2015-2017, z udziałem 10,6\% w 2017 r.), gaz naftowy (w 2018 r. - 11,5\%), złoto (w 2019 r. - 8,64\%).

Zależność między eksportem z Chin do Australii a eksportem z Australii do Chin została zaprezentowana na rys. 9. Jak wynika $z$ analizy tego wykresu, istnieje duża korelacja wymiany handlowej między oboma krajami, przy czym w wypadku zakupu przez Australię towarów z Chin dotyczy ona przede wszystkim wspomnianych już komputerów, natomiast w wypadku sprzedaży towarów przez Australię do Chin surowców - głównie rudy żelaza. Współczynnik korelacji wyniósł 0,97. 


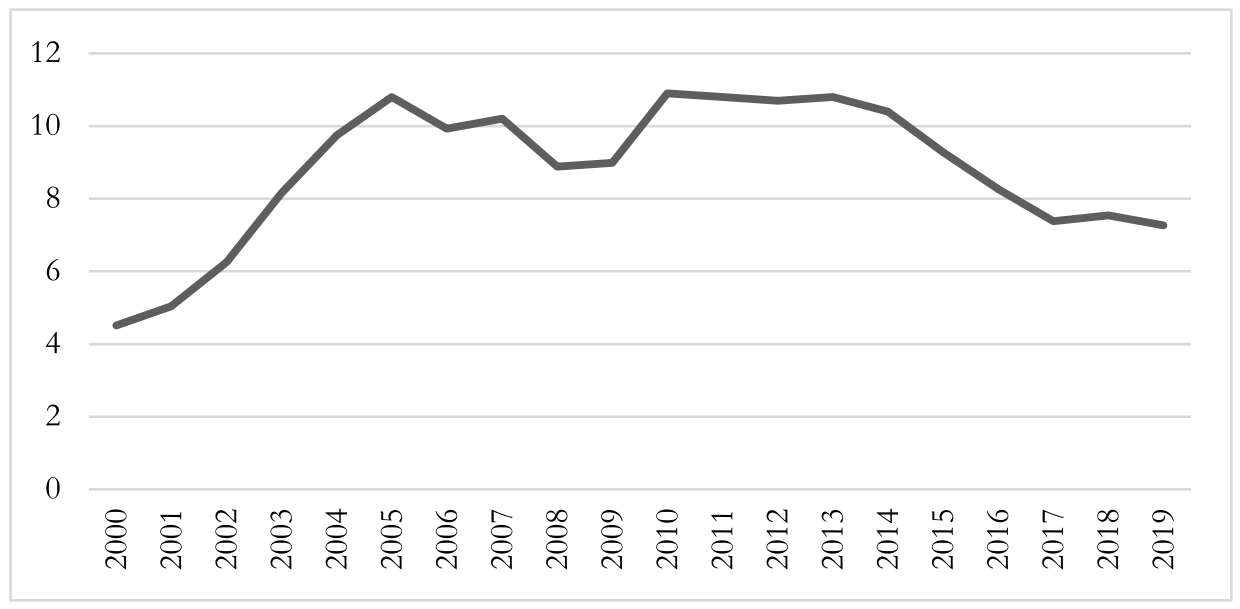

Rys. 7. Udział komputerów w eksporcie towarowym z Chin do Australii (\%)

Źródło: Opracowanie własne na podstawie OEC, https://oec.world/ (dostęp: 22.07.2021).

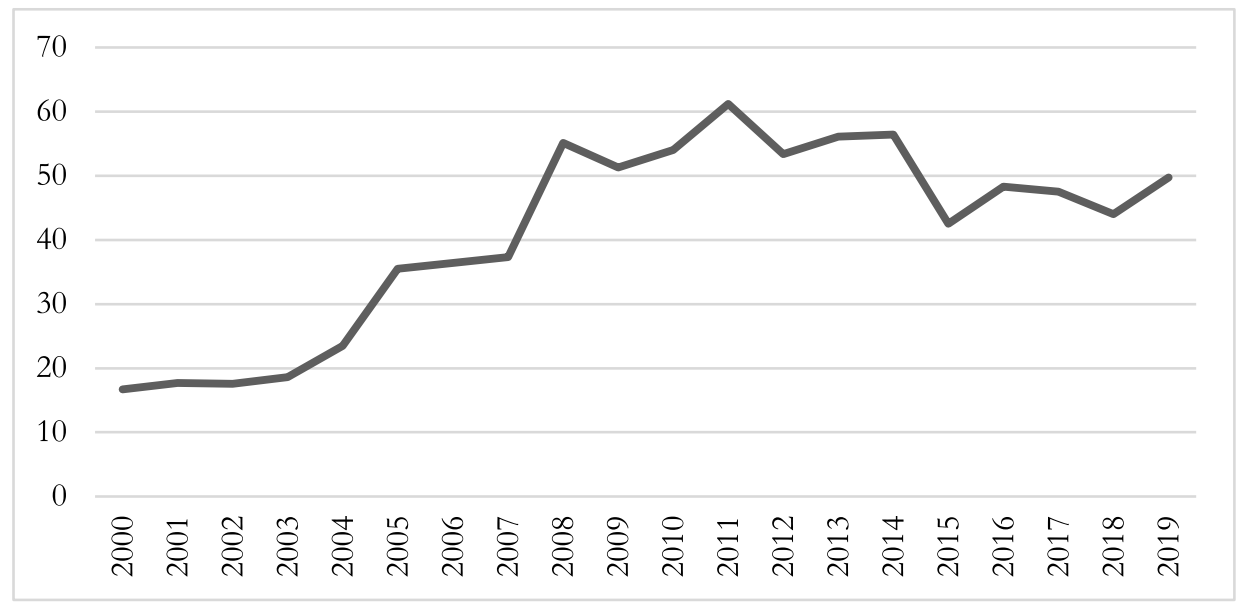

Rys. 8. Udział rudy żelaza w eksporcie towarowym z Australii do Chin (\%)

Źródło: Opracowanie własne na podstawie OEC, https://oec.world/ (dostęp: 22.07.2021). 


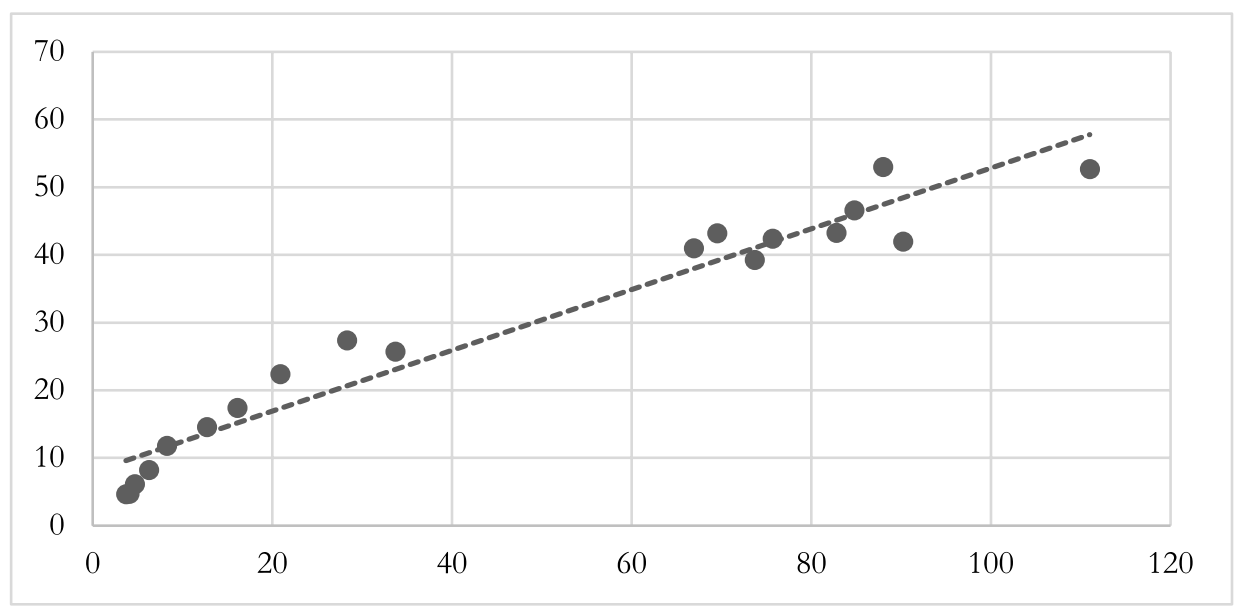

Rys. 9. Zależność między eksportem z Chin do Australii a eksportem z Australii do Chin (mld USD)

Źródło: Opracowanie własne na podstawie OEC, https://oec.world/ (dostęp: 22.07.2021).

Uwzględniając omówione wcześniej dane dotyczące 2019 r., na rys. 10 przedstawiono dziesięć najważniejszych towarów eksportowanych z Chin do Australii, natomiast na rys. 11 pięć najważniejszych towarów, których łączny udział stanowi prawie 1/4 chińskiego eksportu. Na rysunkach 12 i 13 ukazane zostały analogicznie dane dotyczące eksportu z Australii do Chin.

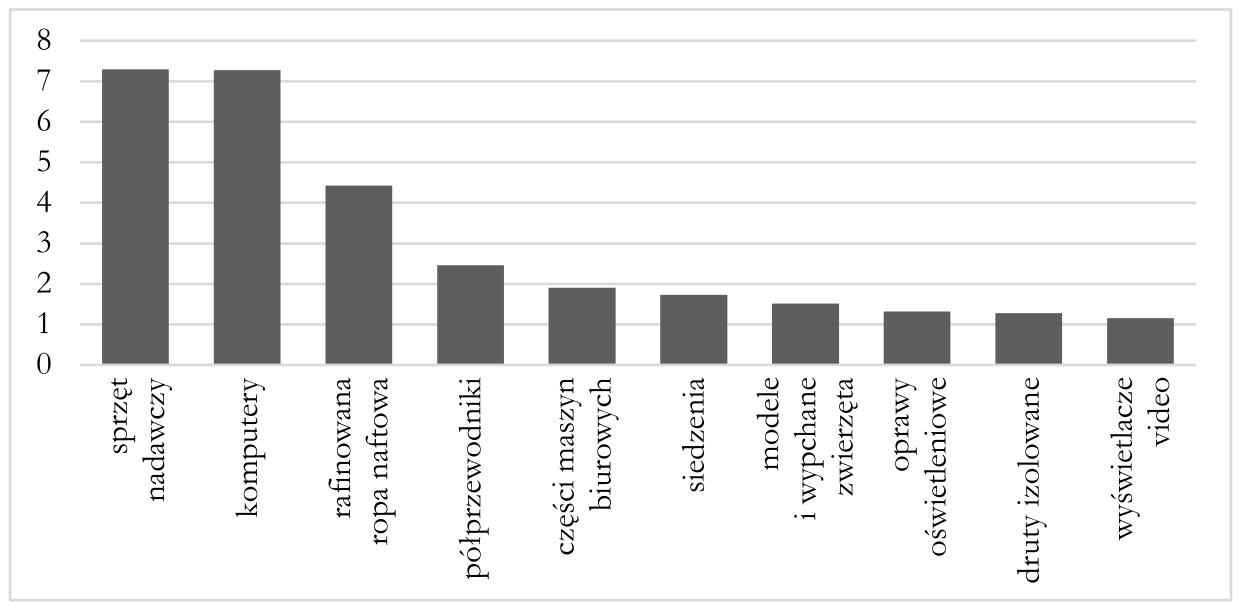

Rys. 10. Udział procentowy dziesięciu najważniejszych towarów w eksporcie z Chin do Australii w $2019 \mathrm{r}$.

Źródło: Opracowanie własne na podstawie OEC, https://oec.world/ (dostęp: 20.07.2021). 


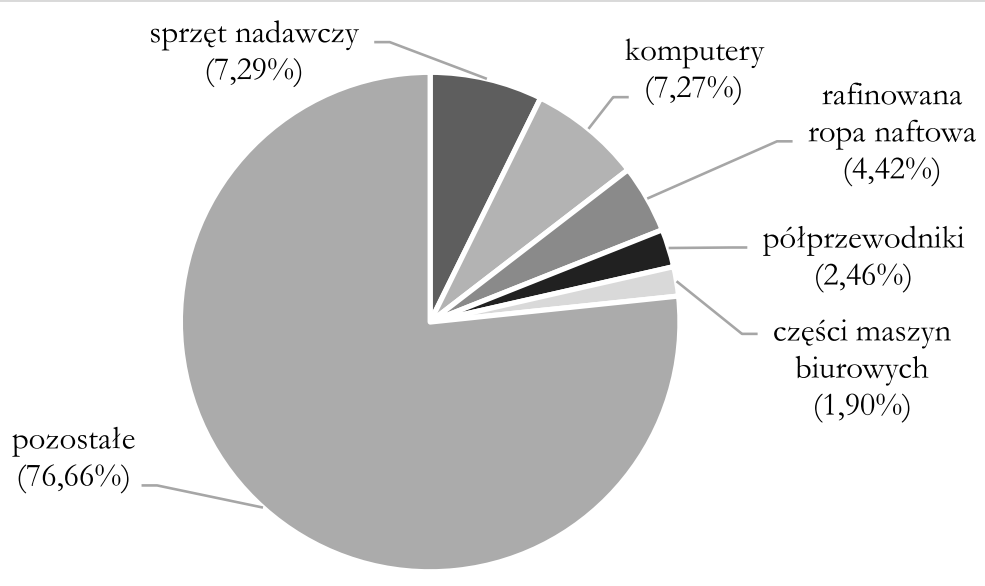

Rys. 11. Pięć towarów z największym udziałem w eksporcie z Chin do Australii w 2019 r. Źródło: Opracowanie własne na podstawie OEC, https://oec.world/ (dostęp: 20.07.2021).

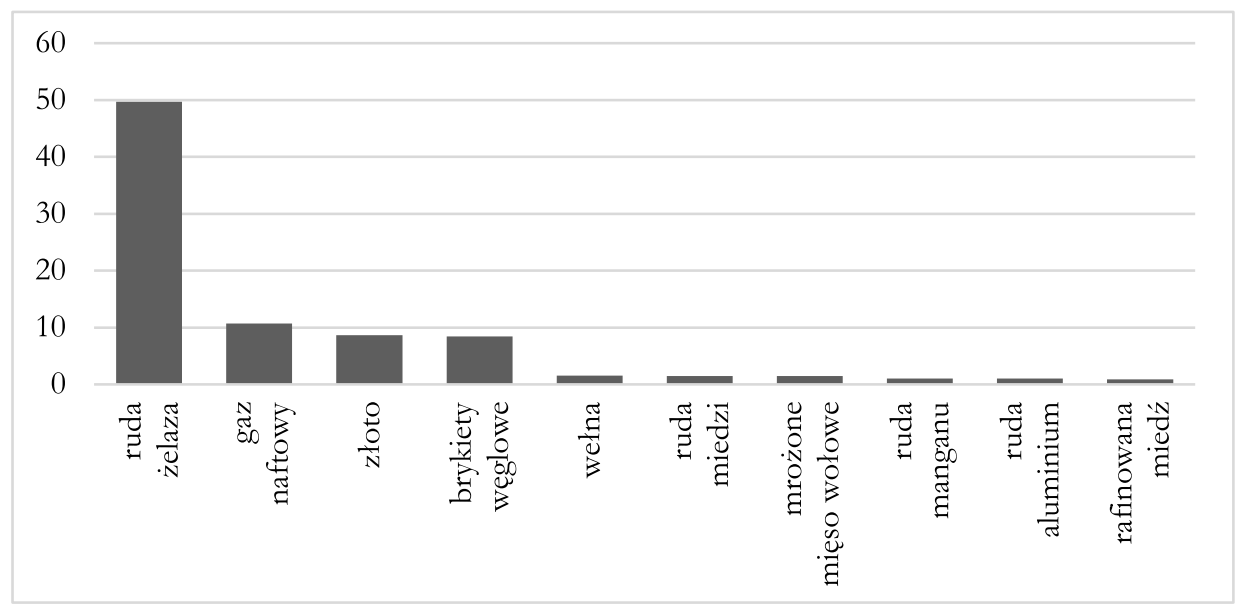

Rys. 12. Udział procentowy dziesięciu najważniejszych towarów w eksporcie z Australii do Chin w 2019 r.

Źródło: Opracowanie własne na podstawie OEC, https://oec.world/ (dostęp: 22.07.2021).

Podsumowując, z danych zaprezentowanych na rys. 11 wynika, że do pięciu najważniejszych towarów eksportowanych z Chin do Australii w 2019 r. należały: sprzęt nadawczy, komputery, rafinowana ropa naftowa, półprzewodniki i części maszyn biurowych. Warto podkreślić, że pozostałe towary stanowiły 77\% eksportu Państwa Środka do Australii, co wskazuje na duże rozproszenie, które należy rozumieć jako eksport wielu grup towarowych, ale w niewielkich ilościach. Natomiast 


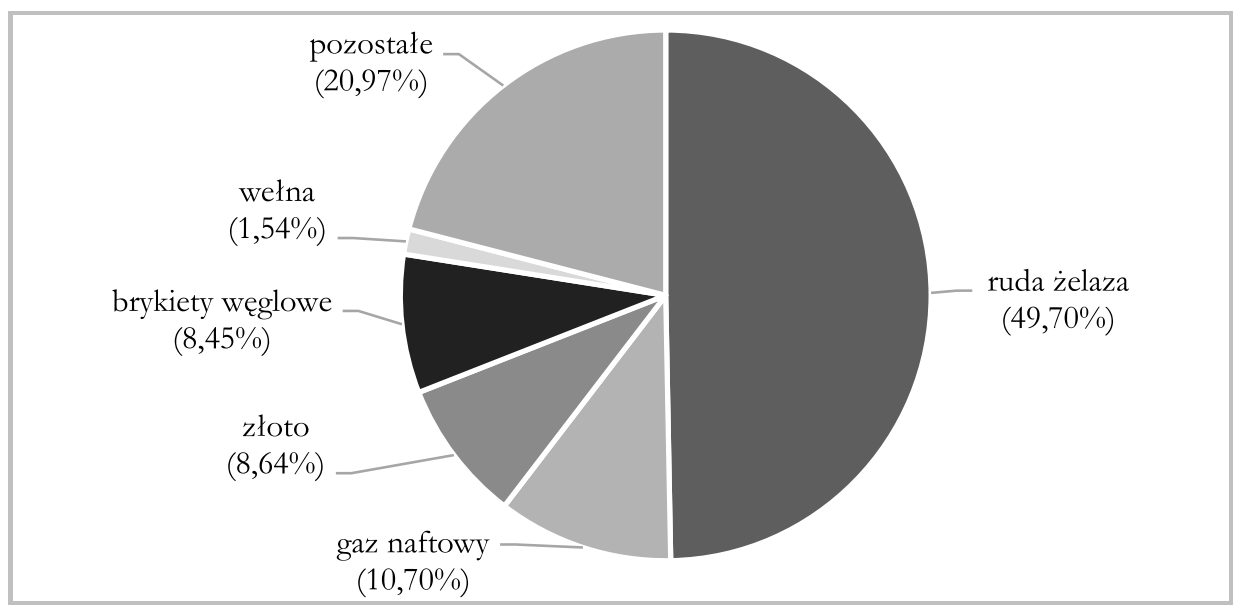

Rys. 13. Pięć towarów z największym udziałem w eksporcie z Australii do Chin w 2019 r. Źródło: Opracowanie własne na podstawie OEC, https://oec.world/ (dostęp: 22.07.2021).

w przypadku Australii pozostałe towary stanowiły nieco ponad 20\% całego australijskiego eksportu do Chin, co znaczy, że na 80\% eksportu składa się jedynie pięć towarów, do których należą: ruda żelaza, gaz naftowy, złoto, brykiety węglowe i wełna. Największy jest udział rudy żelaza, który stanowi prawie połowę (49,7\%) całego eksportu towarowego z Australii do Chin, wskazując jednocześnie na silne uzależnienie Australii od chińskiego popytu na ten surowiec.

Australia zbudowała swoje bogactwo na eksporcie kopalin, produktów pochodzenia rolniczego i usług edukacyjnych do Chin, będąc jednocześnie sojusznikiem $\mathrm{USA}^{55}$. Dynamicznie rozwijający się handel towarowy między Australią a Chinami został poważnie zachwiany w 2020 r. Rok ten przeszedł do historii jako rok ogłoszenia pandemii COVID-19, a w kontekście australijsko-chińskich relacji handlowych dodatkowo jako rok podpisania umowy RCEP oraz rozpoczęcia bilateralnej wojny handlowej.

\section{Rok 2020 - powstanie RCEP,} czyli największej na świecie umowy o wolnym handlu

W ramach odbywającego się w formule on-line w Hanoi 37. szczytu ASEAN 15 listopada 2020 r. piętnaście państw podpisało umowę o utworzeniu Regionalnego Kompleksowego Partnerstwa Gospodarczego (RCEP). Porozumienie zawarło dziesięciu

55 \#Tydzieńw Aziji: Ponad 200-procentowe cta. Eksport ₹. Australii dalej pod presja Pekinu, Instytut Boyma, 6.04.2021, https://www.wnp.pl/rynki-zagraniczne/tydzienwazji-ponad-200-procentowe-cla-eksport-z-australii-dalej-pod-presja-pekinu,460615.html (dostęp: 22.07.2021). 
członków ASEAN, do których należą: Filipiny, Indonezja, Malezja, Singapur, Tajlandia, Brunei, Wietnam, Laos, Mjanma, Kambodża, a ponadto Japonia, Korea Południowa, Chiny, Australia i Nowa Zelandia. W wyniku jego zatwierdzenia powstała największa na świecie strefa wolnego handlu, obejmująca blisko 1/3 ludności świata i 1/3 światowej gospodarki. Umowa RCEP przewiduje obniżenie albo likwidację ceł według ustalonych harmonogramów w okresie maksymalnie 20 lat. Chiny niewątpliwie skorzystają na RCEP, ponieważ dodatkowe ożywienie współpracy handlowej z państwami sąsiednimi może zrekompensować spadek amerykańsko-chińskiej wymiany towarowej, będącej skutkiem wojny handlowej prowadzonej między Stanami Zjednoczonymi a Państwem Środka ${ }^{56}$.

Celem RCEP jako wszechstronnego, kompleksowego i obejmującego szeroki zakres dziedzin porozumienia jest usprawnienie współpracy gospodarczej między krajami Azji i Pacyfiku m.in. poprzez uzupełnienie istniejących między państwami członkowskimi umów o wolnym handlu np. o reguły pochodzenia towarów, ułatwiające funkcjonowanie łańcuchów dostaw ${ }^{57}$. Umowa RCEP jest przykładem zacieśniającej się w ostatnich latach integracji w regionie Azji i Pacyfiku ${ }^{58}$ oraz wyrazem sprzeciwu wobec protekcjonistycznych tendencji występujących w handlu międzynarodowym, w tym ze strony Stanów Zjednoczonych w stosunku do Chin.

Negocjacje zmierzające do powołania nowego międzyregionalnego porozumienia integracyjnego RCEP zostały zainicjowane już w 2012 r. i planowano je zakończyć w 2016 r. Motywy poszczególnych krajów były podobne - wzrost obrotów handlowych między krajami partnerskimi. W wypadku Australii obroty te obejmuja $60 \%$ ich globalnych obrotów handlowych i 70\% eksportu towarów i usług ${ }^{59}$. Data podpisania RCEP nie była przypadkowa. Spotkanie odbyło się przed zaprzysiężeniem nowego prezydenta USA, przypieczętowując klęskę dotychczasowej polityki Donalda Trumpa w regionie ${ }^{60}$.

Zawieranie umów o wolnym handlu stanowi skuteczny sposób na zwiększenie obrotów handlowych czy też inwestycji. W odniesieniu do RCEP negocjacje obejmuja: handel towarowy, usługowy, inwestycje, współpracę gospodarcząi techniczną,

56 K. Rumiński, Regionalne Kompleksowe Partnerstwo Gospodarcze (RCEP) podpisane. Japonia w najwiekeszej na świecie strefie wolnego handlu, Komentarz Ośrodka Badań Azji Centrum Badań nad Bezpieczeństwem Akademii Sztuki Wojennej, komentarz nr 38/2020.

57 K. Żołądkiewicz, W szechstronne Regionalne Partnerstwo Ekonomiczne (RCEP) jako praykkład nowego trendu w regionalizmie, „Finanse, Rynki Finansowe, Ubezpieczenia” 2016, nr 3.

58 Innym przykładem jest porozumienie transpacyficzne CPTPP (ang. The Comprehensive and Progressive Agreement for Trans-Pacific Partnership); zob. D. Wnukowski, Komentar₹ PISM: Porozumienie transpacyficzne bez. US A, komentarz nr 17/2018, https://pism.pl/publikacje/Komentarz_PISM_Porozumienie_transpacyficzne_bez_USA (dostęp: 22.07.2021).

59 Trade and Investment, Australian Government, Department of Foreign Affairs and Trade, https://www.dfat.gov.au/trade/trade-and-investment (dostęp: 22.07.2021).

${ }_{60}$ RCEP, najwieksza umowa o wohym handlu, https://przedsiebiorcy.eu/rcep-najwieksza-umowa-o-wolnym-handlu/ (dostęp: 22.07.2021). 
własność intelektualna, konkurencję, rozstrzyganie sporów oraz inne kwestie. Prognozuje się, że wzrost wymiany handlowej w ramach RCEP pobudzi produkcję i popyt na usługi w państwach spoza porozumienia, a to miałoby pozytywny wpływ na światowa gospodarkę. Umowa ta według The Peterson Institute for International Economics może przyczynić się do wzrostu światowego PKB o 186 mld USD rocznie do 2030 r. Jej wpływ na kształtowanie globalnych zasad handlowych może być jednak ograniczony z powodu nieuwzględnienia zasad w zakresie kwestii środowiskowych czy praw pracowniczych ${ }^{61}$.

Umowa RCEP stanowi wyraz zacieśniającej się integracji w regionie oraz wzmocnienia w nim pozycji Chin i organizacji ASEAN, przy jednoczesnym osłabieniu wpływów USA, co stanowi wyzwanie dla Unii Europejskiej w związku z możliwością zmniejszenia jej handlu z państwami RCEP na rzecz wymiany pomiędzy członkami porozumienia ${ }^{62}$. Poza tym megaregionalne porozumienia handlowe, takie jak RCEP, moga doprowadzić do sytuacji, w której pewne państwa będą objęte wzajemnie nakładającymi się umowami, wywołując tzw. efekt spaghetti (ang. noodle bowl). Porozumienie RCEP, pogłębiające integrację wewnątrz i zrywające powiązania z podmiotami znajdującymi się na zewnątrz, jest coraz częściej postrzegane jako rodzaj Pax Sinica, który włącza kraje regionu, de facto oznaczając rozbudowanie ASEAN, do porządku międzynarodowego zdominowanego przez Chiny ${ }^{63}$.

Protekcjonistyczne zaburzenia w handlu spowodowane sporem pomiędzy Chinami a Stanami Zjednoczonymi oraz ogłoszeniem pandemii COVID-19 wpłynęły na przyspieszenie decyzji o podpisaniu RCEP. Paradoksalnie zawirowania wynikające z ogłoszenia pandemii, które przyczyniły się do zawarcia tej umowy, stały się jednocześnie spiritus movens zaostrzenia wojny handlowej pomiędzy Australią a Chinami, bo zatwierdzono RCEP pomimo trwającego między nimi konfliktu polityczno-handlowego.

\section{Wojna handlowa, czyli odpowiedź Chin na działania dyplomatyczne Australii}

Odpowiedzią Chin na zgłoszony w kwietniu 2020 r. australijski postulat przeprowadzenia międzynarodowego dochodzenia w sprawie roli Chin w wybuchu pandemii COVID-19 był wzrost restrykcji w chińskim imporcie z Australii. Należy jednak

61 D. Wnukowski, Podpisanie RCEP - najwiekeszej na świecie umowy o wolnym handlu, komentarz nr 84, https://pism.pl/publikacje/Podpisanie_RCEP__najwiekszej_na_swiecie_umowy_o_wolnym_ handlu (dostęp: 22.07.2021).

62 Ibidem.

63 D. Fickling, Umowa RCEP to nowy Pax Sinica. Bardziej niž, wolny handel praypomina imperialny system preferencii (Opinia), 19.11.2020, https://forsal.pl/swiat/usa/artykuly/8012779,umowa-rcep-to-nowy-pax-sinica-bardziej-niz-wolny-handel-przypomina-imperialny-system-preferencji-opinia. html (dostęp: 22.07.2021). 
dodać, że relacje gospodarcze między Australią a Chinami uległy pogorszeniu już wcześniej, z tą różnica, że nie znajdowały odbicia we wzajemnych obrotach handlowych, co zostało przedstawione na rys. 1. Przykładowo w 2016 r. rząd australijski wykluczył chińskich operatorów z przetargów związanych z projektami dotyczącymi dystrybucji energii elektrycznej, a w 2018 r., ze względów bezpieczeństwa, nie zgodził się na zaangażowanie koncernu Huawei w budowę infrastruktury sieci $5 \mathrm{G}^{64}$. Mimo wojny handlowej RCEP zostało podpisane, ale wkrótce okazało się, że nie stanowi ono przeszkody w dalszym przykładnym karaniu Australii za zajmowanie, w pewnych kwestiach, odmiennego od Państwa Środka stanowiska. Zaledwie bowiem trzy dni po podpisaniu RCEP, w odpowiedzi na wspomniany dyplomatyczny postulat dotyczący przeprowadzenia śledztwa w sprawie znaczenia Chin w powstaniu pandemii COVID-19, chiński MSZ przedstawił listę „,14 pretensji” wobec rządu Australii. Przedstawiona w tabeli 2 lista spornych kwestii została określona przez Chiny jako zatruwająca bilateralne relacje ${ }^{65}$. Jednocześnie należy ją uznać za, opracowaną listę ostrzegawczą dla innych krajów, w sytuacji, gdyby zdecydowały się one otwarcie krytykować Chiny i domagać się przeprowadzenia dochodzenia w sprawie wybuchu pandemii, winiąc za to Państwo Środka ${ }^{66}$.

Tabela 2. Lista „14 pretensji”

\begin{tabular}{|c|c|}
\hline Numer & Treść pretensji \\
\hline 1 & $\begin{array}{l}\text { Decyzje o zablokowaniu inwestycji zagranicznych, podejmowane na podstawie } \\
\text { niejasnych powodów związanych z bezpieczeństwem narodowym, z naruszeniem } \\
\text { zasad CHAFTA - od } 2018 \text { r. ponad } 10 \text { chińskich projektów inwestycyjnych zostało } \\
\text { odrzuconych przez Australię, powołującą się na niejednoznaczne i nieuzasadnione } \\
\text { „obawy bezpieczeństwa narodowego” i nakładającą ograniczenia w takich } \\
\text { obszarach, jak: infrastruktura, rolnictwo i hodowla zwierząt }\end{array}$ \\
\hline 2 & $\begin{array}{l}\text { Decyzja blokująca koncernom Huawei Technologies i ZTE dostęp do sieci 5G, } \\
\text { podjęta na podstawie nieuzasadnionych obaw o bezpieczeństwo narodowe, zgodna } \\
\text { z linią USA, które przekonują inne kraje do podejmowania takich działań }\end{array}$ \\
\hline 3 & Ustawodawstwo dotyczące ingerowania w wewnętrzne sprawy Chin \\
\hline 4 & $\begin{array}{l}\text { Upolitycznienie i stygmatyzacja normalnych wymian i współpracy między Chinami } \\
\text { a Australią oraz tworzenie barier i narzucanie restrykcji, w tym anulowanie wiz dla } \\
\text { chińskich stypendystów }\end{array}$ \\
\hline
\end{tabular}

${ }^{64}$ M. Ciesielski, Konsekwencje chinsko-australijskiej wojny handlowej, 4.03.2021, https://www.obserwatorfinansowy.pl/tematyka/makroekonomia/trendy-gospodarcze/konsekwencje-chinsko-australijskiej-wojny-handlowej/ (dostęp: 22.07.2021).

65 R. Smith, China leaks dossier of 14 disputes with Australia as tensions increase, https://news.knowledia.com/AU/en/articles/china-leaks-dossier-of-14-disputes-with-australia-as-tensions-increase-c376c215015ef29454aab44c8ea564b1a221dc8a (dostęp: 22.07.2021).

${ }^{66}$ H. Kozieł, Chinski atak na antypody, 14.12.2020, https://www.parkiet.com/Gospodarka---Swiat/312149994-Chinski-atak-na-antypody.html (dostęp: 22.07.2021). 


\begin{tabular}{|c|l|}
\hline Numer & \multicolumn{1}{|c|}{ Treść pretensji } \\
\hline 5 & $\begin{array}{l}\text { Żądanie przeprowadzenia międzynarodowego niezależnego śledztwa w sprawie } \\
\text { wirusa wywołującego COVID-19 jako polityczna manipulacja naśladująca atak USA } \\
\text { na Chiny }\end{array}$ \\
\hline 6 & $\begin{array}{l}\text { Nieustanna bezmyślna ingerencja w chińskie sprawy Xinjiangu, Hongkongu } \\
\text { i Tajwanu; przewodzenie krucjacie przeciwko Chinom na niektórych forach } \\
\text { wielostronnych }\end{array}$ \\
\hline 7 & $\begin{array}{l}\text { Pierwsze nienadmorskie państwo wydające oświadczenie na temat Morza } \\
\text { Południowochińskiego dla ONZ }\end{array}$ \\
\hline 8 & $\begin{array}{l}\text { Bycie po stronie amerykańskiej, antychińskiej kampanii i rozpowszechnianie } \\
\text { dezinformacji zapożyczonej z USA w odniesieniu do chińskich wysiłków } \\
\text { zmierzających do powstrzymania COVID-19 }\end{array}$ \\
\hline 9 & $\begin{array}{l}\text { Najnowsze ustawodawstwo, którego zadaniem jest analizowanie ugód } \\
\text { z zagranicznymi rządami, wymierzone w Chiny i mające na celu storpedowanie } \\
\text { Victorian Participation in B\&R }\end{array}$ \\
\hline 10 & $\begin{array}{l}\text { Zapewnienie finansowania antychińskich grup ekspertów (think tank) w celu } \\
\text { rozpowszechniania nieprawdziwych raportów, propagowania kłamstw dotyczących } \\
\text { Xinjiangu i tzw. chińskiej infiltracji, tak aby zmanipulować opinię publiczną } \\
\text { i obrócić ją przeciwko Chinom }\end{array}$ \\
\hline 11 & $\begin{array}{l}\text { Dokonywanie wczesnym świtem przeszukań domów i własności chińskich } \\
\text { dziennikarzy oraz lekkomyślne ich przejmowanie bez przedstawienia żadnych } \\
\text { zarzutów i jakichkolwiek wyjaśnień }\end{array}$ \\
\hline 12 & $\begin{array}{l}\text { Słabo zawoalowane zarzuty wobec Chin dotyczące cyberataków pozbawione } \\
\text { jakichkolwiek dowodów }\end{array}$ \\
\hline $\begin{array}{l}\text { Skandaliczne potępienie partii rządzącej Chin przez posłów i rasistowskie ataki na } \\
\text { Chińczyków czy Azjatów }\end{array}$ \\
\hline $\begin{array}{l}\text { Nieprzychylne lub antagonistyczne doniesienia mediów na temat Chin, zatruwające } \\
\text { atmosferę w stosunkach dwustronnych }\end{array}$ \\
\hline 14
\end{tabular}

Źródło: The 14 disputes of China to Australia, 23.11.2020, https://www.voltairenet.org/article211799. html (dostęp: 22.07.2021).

Dziesięć dni po ogłoszeniu listy „14 pretensji”, czyli 28 listopada 2020 r., Chiny nałożyły karne cło (antydumpingowe) w wysokości od 107,1\% do 212,1\% na australijskie wina, które są bardzo popularne w Państwie Środka. Zważywszy że prawie $40 \%$ australijskiego wina eksportuje się do Chin, jego producenci ponieśli ogromne straty finansowe. Rynek wina w Australii jest wyceniany na 2,9 mld AUD rocznie. Oficjalną przyczyną nałożenia ceł na australijskie wina były duże straty ponoszone przez chińskich producentów, którzy nie mogą konkurować z tańszymi winami z Chin ${ }^{67}$. Eksport win z Australii do Chin o wartości 1 mld USD odnoto-

${ }^{67}$ Chincsycy nato:̇yli gigantyczne cta na australijskie wina, 28.11.2020, https://www.rp.pl/handel/ art8745831-chinczycy-nalozyli-gigantyczne-cla-na-australijskie-wina (dostęp: 22.07.2021). 
wał spadek o 96\% w pierwszym kwartale $2021 \mathrm{r}^{68}$ Skutkiem wprowadzenia ceł jest poszukiwanie przez Australię nowych rynków zbytu. Dzięki podpisanym umowom o wolnym handlu z innymi gospodarkami regionu możliwy stał się eksport wina do Singapuru, Tajlandii, Malezji, Korei Południowej, Japonii, Indonezji i Hongkongu ${ }^{69}$. Ponadto Australia zwiększyła eksport win do Wielkiej Brytanii ${ }^{70}$.

Trudna sytuacja dotyczyła również jęczmienia, którego 70\% produkcji jest eksportowane do Chin. Nałożenie cła w wysokości 80\% na importowany z Australii jęczmień stanowiło poważny problem dla australijskich rolników. Cłami objęto też australijskie drewno - wskazano jako oficjalną przyczynę istnienie groźnych szkodników w niektórych partiach ${ }^{71}$, a następnie wykrycie „zagrożenia biologicznego"72. W ramach wojny handlowej, chociaż należałoby raczej mówić o wojnie polityczno-gospodarczej, Chiny nakładają cła na produkty będące najważniejszymi australijskimi towarami eksportowymi do Państwa Środka. Innymi słowy, Chiny objęły cłami produkty, które mogą importować z innych krajów, nie nałożyły więc cła na rudę żelaza, ponieważ w warunkach ogłoszonej pandemii nie miały alternatywnego rynku importowego. Ruda żelaza stanowi istotny surowiec dla rozwoju chińskiej gospodarki. Jest on jednocześnie trudny do zastąpienia ze względu na niedobór na światowych rynkach. Australijski eksport rudy to $60 \%$ chińskiego importu ${ }^{73}$. Prognozuje się w tym kontekście, że już od 2025 r. importowane złoża z zachodnioafrykańskiej Gwinei uniezależnią Chiny od australijskiej rudy żelaza ${ }^{74}$. Wówczas Australia może mieć problem ze sprzedażą tego surowca. Tymczasem Australia dąży do uniezależnienia się od chińskiego importu pierwiastków ziem rzadkich, finansując przywrócenie wydobycia wolframu w kopalni na Tasmanii, która została zamknięta 30 lat temu ${ }^{75}$.

Chiny nałożyły także cła na inne towary australijskie, np. miedź, wołowinę, baraninę, bawełnę, wełnę. Konsekwencję limitowania eksportu odczuwają przede

${ }^{68}$ J. Perzyński, Australia nygrywa spór handlowy z Chinami, 7.06.2021, https://biznesalert.pl/chiny-australia-wegiel-surowce-energetyka/ (dostęp: 22.07.2021).

69 Ibidem.

70 Brytyjcaycy przechwycili australijskie wina, których nie chcieli Chińcsycy, 4.02.2021, https://www. rp.pl/handel/art292571-brytyjczycy-przechwycili-australijskie-wina-ktorych-nie-chcieli-chinczycy (dostęp: 22.07.2021).

71 Chincsycy natosyli gigantyczne cła...

72 Nasila sie konfliket handlowy miedzy Chinami a Australia, 2.11.2020, https://forsal.pl/swiat/ chiny/artykuly/7994687, nasila-sie-konflikt-handlowy-miedzy-chinami-a-australia.html (dostęp: 22.07.2021).

73 M. Ciesielski, Konsekwencje chinsko-australijskiej wojny...

74 Por. \#Tydzieńw Azji: Ponad 200-procentowe cta...; Ch. Le Bec, Guinea/China: Negotiations turn complicated over Simandou iron ore project, 11.05.2021, https://www.theafricareport.com/86786/guinea-china-negotiations-turn-complicated-over-simandou-iron-ore-project/ (dostęp: 22.07.2021).

75 M. Ciesielski, Konsekwencje chińsko-australijskiej wojny... 
wszystkim australijscy producenci. Przykładowo, nałożenie ceł na australijskie homary w sytuacji, gdy 90\% ich eksportu trafia na rynek chiński, może doprowadzić do załamania się całej tej branży ${ }^{76}$.

Chiński rynek jest bardzo chłonny i tworzy dodatkowe szanse rozwoju dla eksporterów, dlatego niewiele państw otwarcie popiera działania polityczne realizowane przeciw rządowi ChRL. Australia, podejmując ten krok, nie tylko wywołała kryzys wśród australijskich producentów, lecz także ukazała, że Chiny, stosując embargo jako sposób na wywarcie presji politycznej i gospodarczej, poniosły straty. Tak było w wypadku gazu skroplonego LNG czy węgla. Australia, posiadając bardzo zaawansowaną technologię wydobycia i dostaw, jest największym dostawca tego surowca i Chinom trudno będzie znaleźć innego. Chiny, rezygnując z australijskiego węgla, zostały zmuszone do szukania nowych dostawców, którzy okazali się nierentowni, co skutkuje wyższą ceną za tę samą wartość kaloryczną (import z Rosji) lub niższą jakość (import z Indonezji). Embargo zmusza jednocześnie Australię do poszukiwania nowych rynków zbytu - w odniesieniu do wspomnianego węgla takim rynkiem są np. Indie (w grudniu 2020 r. eksport węgla do Indii wzrósł o 450\% ${ }^{77}$. Paradoksalnie chińskie embargo na węgiel najbardziej odczuły Chiny, gdy cena surowca na tamtejszym rynku w okresie od maja 2020 r. do stycznia 2021 r. wzrosła o $88 \%{ }^{78}$.

$\mathrm{Na}$ działania Chin (cła, embargo, środki pozataryfowe) Australia nie odpowiedziała jednak wprowadzeniem ceł odwetowych $-z$ uwagi na ich konsekwencje dla australijskiego eksportu. Chińskie restrykcje handlowe zmusiły jednocześnie do podjęcia dyskusji dotyczącej ekonomicznego uzależnienia Australii od Państwa Środka, gdzie trafia 40\% eksportu australijskich towarów i ponad 15\% usług. Wstępne szacunki wykazuja, że chińskie sankcje, mimo że objęły trzynaście sektorów gospodarki, w niewielkim stopniu wpłynęły na australijski eksport do Chin (por. rys. 5). Stało się tak głównie za sprawą wysokich cen rudy żelaza. Jak na razie skutki dla pojedynczych producentów są trudne do oszacowania. Z pewnością część australijskich branż poniosła ogromne straty, ale ogólnie Australia stała się beneficjentem wzrostu cen surowców ${ }^{79}$, zaś australijskie przedsiębiorstwa uzyskały imperatyw do dywersyfikacji eksportu ${ }^{80}$. Niniejsze opracowanie dotyczy wprawdzie

\footnotetext{
76 A. Wolska, Chiny wstryymaja import ₹. Australii wart nawet 6 mld dolarów?, 6.11.2020, https:// www.euractiv.pl/section/bezpieczenstwo-i-obrona/news/chiny-wstrzymaja-import-z-australii-wart-nawet-6-mld-dolarow/ (dostęp: 22.07.2021).

77 J. Perzyński, Australia wygrywa spór handlowy...

78 M. Ciesielski, Konsekwencje chinsko-australijskiej wojny...

79 Ibidem.

80 S. Roggeveen, Why Australia should respond to China's provocations with self-reliance, 9.12.2020, https://www.lowyinstitute.org/publications/why-australia-should-respond-china-s-provocations-self-reliance (dostęp: 22.07.2021).
} 
handlu towarowego, ale nie sposób nie podkreślić, że w wyniku wojny handlowej może również ucierpieć australijski sektor edukacji1 ${ }^{81}$.

Skutkiem wojny handlowej jest zbliżenie Australii z innymi krajami, które są sceptyczne wobec działań Chin. Przykładem jest podpisanie w 2021 r. traktatu o współpracy obronnej z Japonią. Biorąc jednocześnie pod uwagę wcześniejsze wojny handlowe Chin z innymi krajami, optymizmem napawa fakt, że po pewnym czasie relacje gospodarcze pomiędzy ChRL a „ukaranymi” krajami zawsze wracały do normy ${ }^{82}$. W kontekście znaczenia bilateralnego handlu między obydwoma krajami dla przyszłego wzrostu gospodarczego Australii, jest to kluczowa kwestia ${ }^{83}$. Mimo politycznych napięć między Australią a ChRL bilateralne relacje handlowe, jak wynika z przeprowadzonej wcześniej analizy, są silne i będą się umacniać, przy jednoczesnym poszukiwaniu nowych rynków ${ }^{84}$.

Reasumując, mimo podpisania RCEP Chiny rozszerzyły ograniczenia w handlu z Australią, limitując eksport kluczowych towarów dla australijskiej gospodarki. Warto w tym miejscu podkreślić, że oba kraje należą do WTO, a od 2016 r. obowiązuje dwustronna umowa o wolnym handlu ChAFTA, której celem jest ułatwienie i poszerzenie wzajemnej wymiany ${ }^{85}$. Skutkiem australijsko-chińskiej wojny handlowej, która z pewnościa potrwa jeszcze kilka lat, jest dla Chin poszukiwanie nowych dostawców, natomiast dla Australii przekierowywanie eksportu, czyli poszukiwanie nowych rynków zbytu. Wciąż jednak duże uzależnienie australijskiej gospodarki od eksportu do Chin pozwala prognozować dalszy rozwój bilateralnego handlu towarowego. Oba kraje najprawdopodobniej poradzą sobie gospodarczo, ponieważ tocząca się między nimi wojna handlowa ma podłoże polityczne.

\section{Podsumowanie}

Potencjał terytorialny Australii i Chin jest porównywalny, natomiast w odniesieniu do potencjału demograficznego istnieją ogromne dysproporcje między tymi krajami. Lączą je silne powiązania handlowe, które są determinowane popytem Chin

81 Australia kontra Chiny. Eksperci: Sektor edukacji może być nastęnq ofiarq wojny handlowej, 12.05.2021, https://forsal.pl/swiat/aktualnosci/artykuly/8160941, australia-chiny-sektor-edukacji-wojna-handlowa.html (dostęp: 22.07.2021).

82 H. Kozieł, Chinski atak na antypody...

83 E. Albert, China-Australia Slump Continues to Deepen, 11.02.2021, https://thediplomat. com/2021/02/china-australia-slump-continues-to-deepen/ (dostęp: 22.07.2021).

84 D. Fickling, Pomimo ataku gospodarczego Chin na Australie, wajemny handel może rozkwitnać. Jak to mo:́liwe? (Opinia), 4.12.2020, https://forsal.pl/swiat/chiny/artykuly/8030878, chiny-australia-pomimo-ataku-gospodarczego-chin-na-australie-wzajemny-handel-moze-rozkwitnac-jak-to-mozliwe-opinia.html (dostęp: 22.07.2021).

85 Ch. Qi, J.X. Zwang, The economic impacts of the China-Australia Free Trade Agreement-A general equilibrium analysis, „China Economic Review” 2018, vol. 47. 
na australijskie towary, przede wszystkim węgiel i rudę żelaza, a także na usługi turystyczne i edukacyjne. Powiązania te wskazują na silne uzależnienie australijskiej gospodarki od Chin. Australia to wysoko rozwinięty kraj opierający swój eksport na surowcach i płodach rolnych.

$\mathrm{Na}$ tle bilateralnych relacji handlowych uwypukla się wojna handlowa trwająca od co najmniej 2018 r., kiedy to zaostrzyły się globalne napięcia między USA a Chinami. Australia jest najważniejszym sojusznikiem USA w regionie, dlatego przez lata podawana była jako wzorcowy kraj w aspekcie relacji zarówno ze Stanami Zjednoczonymi, jak i z Chinami. Zintensyfikowanie wojny handlowej nastąpiło w $2020 \mathrm{r}$, gdy Australia oficjalnie zaczęła domagać się wszczęcia dochodzenia w sprawie przyczyn globalnej pandemii COVID-19, oskarżając przy tym Chiny. Problem ten, jego waga oraz szczebel polityczny, na jakim zostały sformułowane oskarżenia, skutkowały wprowadzeniem przez Chiny ceł, embarga oraz barier pozataryfowych na kluczowe towary w australijskim eksporcie. Nie przeszkodziło w tym podpisanie umowy o wolnym handlu RCEP, co dało jednocześnie jasny przekaz, że kwestie polityczne mają większe znaczenie niż argumenty ekonomiczne. W najbliższych latach, pomimo wojny handlowej, bilateralne relacje dotyczące towarów będą się rozwijać, ponieważ wynikają z silnego uzależnienia Australii od Chin. Zarazem obie strony poszukują alternatywnych rozwiązań - Chiny w zakresie dostawców, natomiast Australia w odniesieniu do nowych rynków zbytu.

\section{Literatura}

Albert E., China-Australia Slump Continues to Deepen, 11.02.2021, https://thediplomat.com/2021/02/ china-australia-slump-continues-to-deepen/ (dostęp: 22.07.2021).

Australia. Analiza międzynarodowa, Biuro Strategii i Analiz Międzynarodowych PKO Bank Polski SA, 18.08.2020, https://wspieramyeksport.pl/api/public/files/1964/Australia_Analiza_Miedzynarodowa_2020_08.pdf (dostęp: 22.07.2021).

Australia, Directorate General for Trade, European Commission, https://webgate.ec.europa.eu/ isdb_results/factsheets/country/details_australia_en.pdf (dostęp: 22.07.2021).

Australia kontra Chiny. Ekesperci: Sektor edukacji może być nastepna ofiara wojny handlowej, 12.05.2021, https://forsal.pl/swiat/aktualnosci/artykuly/8160941,australia-chiny-sektor-edukacji-wojna-handlowa.html (dostęp: 22.07.2021).

Australia. Przewodnik po rynku, Warszawa 2018.

Australia, The World Factbook, https://www.cia.gov/the-world-factbook/countries/australia/ (dostęp: 22.07.2021).

Australia. Znajdź, rynki eksportowe, https://wspieramyeksport.pl/znajdz-rynki-eksportowe/au/australia (dostęp: 22.07.2021).

Błaszczak J., Stosunki australijsko-chińskie na przestrz̨eni XX wieku i wspótcześnie [w:] Chiny w stosunkach mięsynarodowych, red. M. Pietrasiak, D. Mierzejewski, Łódź - Kurowice 2012. 
Brytyjcsycy pręechwycili australijskie wina, których nie chcieli Chincsycy, 4.02.2021, https://www.rp.pl/ handel/art292571-brytyjczycy-przechwycili-australijskie-wina-ktorych-nie-chcieli-chinczycy (dostęp: 22.07.2021).

China, Directorate General for Trade, European Commission, https://webgate.ec.europa.eu/ isdb_results/factsheets/country/details_china_en.pdf (dostęp: 22.07.2021).

China, The World Factbook, https://www.cia.gov/the-world-factbook/countries/china/ (dostęp: 22.07.2021).

Chiny. Analiza międzynarodowa, Biuro Strategii i Analiz Międzynarodowych PKO Bank Polski SA, 24.06.2020, https://wspieramyeksport.pl/api/public/files/1927/Chiny_Analiza_Miedzynarodowa_2020_06.pdf (dostęp: 22.07.2021).

Chiny. Znajdź, rynki eksportowe, https://wspieramyeksport.pl/znajdz-rynki-eksportowe/cn/chin (dostęp: 22.07.2021).

Chincsycy natożyli gigantyczne cta na australijskie wina, 28.11.2020, https://www.rp.pl/handel/art8745831-chinczycy-nalozyli-gigantyczne-cla-na-australijskie-wina (dostęp: 22.07.2021).

Ciesielski M., Konsekwencje chinsko-australijskiej wojny handlowej, 4.03.2021, https://www.obserwatorfinansowy.pl/tematyka/makroekonomia/trendy-gospodarcze/konsekwencje-chinsko-australijskiej-wojny-handlowej/ (dostęp: 22.07.2021).

Data for China, The World Bank, www.data.worldbank.org (dostęp: 22.07.2021).

Fickling D., Pomimo ataku gospodarčego Chin na Australie, wrajemny handel może rozkwitnać. Jak to mo:̇liwe? (Opinia), 4.12.2020, https://forsal.pl/swiat/chiny/artykuly/8030878, chiny-australia-pomimo-ataku-gospodarczego-chin-na-australie-wzajemny-handel-moze-rozkwitnac-jak-to-mozliwe-opinia.html (dostęp: 22.07.2021).

Fickling D., Umowa RCEP to nowy Pax Sinica. Bardziej niž wolny handel praypomina imperialny system preferencji (Opinia), 19.11.2020, https://forsal.pl/swiat/usa/artykuly/8012779, umowa-rcep-to-nowy-pax-sinica-bardziej-niz-wolny-handel-przypomina-imperialny-system-preferencji-opinia.html (dostęp: 22.07.2021).

Frączyk J., Pompowany wrost Chin. „Te inwestycje nie prazyniosa wysokiego zwrotu”, 19.01.2021, https:// businessinsider.com.pl/finanse/makroekonomia/wzrost-pkb-chin-napompowany-jest-nisko-wydajnymi-inwestycjami/yh8qw8v (dostęp: 22.07.2021).

Gadzała L., Tiananmen: Ile mydarzenia z.1989 r. dziś znaczq dla Chin?, 4.06.2020, https://www.euractiv.pl/section/demokracja/news/tiananmen-ile-wydarzenia-1989-chiny-pekin-4-czerwca-deng-xi-jinping/ (dostęp: 22.07.2021).

General Profile: Australia, UNCTADstat, http://unctadstat.unctad.org/countryprofile/generalprofile/en-gb/036/index.html (dostęp: 22.07.2021).

General Profile: China, UNCTADstat, http://unctadstat.unctad.org/countryprofile/generalprofile/en-gb/156/index.html (dostęp: 22.07.2021).

Hughes H., Australian Exports: Performance, Obstacles and Issues of Assistance, Report of the Committee for Review of Export Market Development Assistance, Hughes Report, Canberra 1989.

Human Development Report 2020: The next frontier Human development and the Anthropocene, New York 2020.

International Monetary Fund, World Economic Outlook. Managing divergent recoveries, [b.m.] 2021.

Jureńczyk Ł., Australijsko-chińskie stosunki gospodarcze w drugiej dekadzie XXI wieku a bezpieczeństwo ekonomiczne Australii, „Rocznik Bezpieczeństwa Międzynarodowego” 2019, t. 13, nr 1.

Jureńczyk L., Polityka bezpieczeństwa i obrony Australii w drugiej dekadzie XXI wieku wobec wzrostu potegi Chin, „Sprawy Międzynarodowe” 2019, t. 72, nr 3. 
Kozieł H., Chinski atak na antypody, 14.12.2020, https://www.parkiet.com/Gospodarka---Swiat/ 312149994-Chinski-atak-na-antypody.html (dostęp: 22.07.2021).

Le Bec Ch., Guinea/China: Negotiations turn complicated over Simandou iron ore project, 11.05.2021, https://www.theafricareport.com/86786/guinea-china-negotiations-turn-complicated-over-simandou-iron-ore-project/ (dostęp: 22.07.2021).

Ludność i gospodarka Australii, 1.07.2019, http://geografia24.pl/ludnosc-i-gospodarka-australii/ (dostęp: 22.07.2021).

Nasila sie konflik.t handlony miedzy Chinami a Australia, 2.11.2020, https://forsal.pl/swiat/chiny/artykuly/7994687,nasila-sie-konflikt-handlowy-miedzy-chinami-a-australia.html (dostęp: 22.07.2021).

Okraska T., Stosunki australijsko-chinskie. Historia, stan obecny, perspektywy [w:] Australia w XX i XXI wieku. Polityka, historia i kultura, red. A. Kandzia-Poździał, J. Siekiera, Katowice 2017.

Oto państwa, z. którymi Cbiny maja ujemny bilans handlowy, 25.08.2017, https://forsal.pl/artykuly/1065651, oto-panstwa-z-ktorymi-chiny-maja-ujemny-bilans-handlowy.html (dostęp: 22.07.2021).

Pandemia koronawirusa czarnym tabedziem, 22.04.2020, https://www.obserwatorfinansowy.pl/forma/ warto-wiedziec/raporty/pandemia-koronawirusa-czarnym-labedziem/ (dostęp: 22.07.2021).

Pangsy-Kania S., Ksztattowanie sie wskaźnika HDI w Chinach w latach 1980-2013 na tle pozostatych krajów BRICS, „Gdańskie Studia Azji Wschodniej” 2015, z. 8.

Pangsy-Kania S., Od „Made in China” do „Created in China” - droga Chin do supremacji innowacyjnej, „Gdańskie Studia Azji Wschodniej” 2021, z. 19.

Paszak P., Chiny starzeja sie w blyskawicznym tempie, 26.11.2020, https://warsawinstitute.org/pl/chiny-starzeja-sie-w-blyskawicznym-tempie/ (dostęp: 22.07.2021).

Perzyński J., Australia nygrywa spór handlowy z Chinami, 7.06.2021, https://biznesalert.pl/chiny-australia-wegiel-surowce-energetyka/ (dostęp: 22.07.2021).

Qi Ch., Zwang J.X., The economic impacts of the China-Australia Free Trade Agreement-A general equilibrium analysis, „China Economic Review” 2018, vol. 47.

RCEP, najwiekesza umowa o wolnym handlu, https://przedsiebiorcy.eu/rcep-najwieksza-umowa-o-wolnym-handlu/ (dostęp: 22.07.2021).

Relacje handlowe międyy Chinami i Australiq, 19.04.2021, https://www.coface.pl/Aktualnosci-i-media/Biuro-prasowe/Relacje-handlowe-miedzy-Chinami-i-Australia (dostęp: 22.07.2021).

Roggeveen S., Why Australia should respond to China's provocations with self-reliance, 9.12.2020, https://www.lowyinstitute.org/publications/why-australia-should-respond-china-s-provocations-self-reliance (dostęp: 22.07.2021).

Rumiński K., Regionalne Kompleksowe Partnerstwo Gospodarcze (RCEP) podpisane. Japonia w największej na śniecie strefie wolnego handlu, Komentarz Ośrodka Badań Azji Centrum Badań nad Bezpieczeństwem Akademii Sztuki Wojennej, komentarz nr 38/2020.

Sheng Y., Song L., Comparative advantage and Australia-China bilateral trade, „Economic Papers” 2008, vol. 27, no. 1.

Ślazyk L., Chiny-Australia - między pycha a desperacja. Polityka któci sie z biznesem, Podróż bez Paszportu, https://www.youtube.com/watch?v=_WlGR_ZPNm8 (dostęp: 22.07.2021).

Smith R., China leaks dossier of 14 disputes with Australia as tensions increase, https://news.knowledia.com/AU/en/articles/china-leaks-dossier-of-14-disputes-with-australia-as-tensions-increase-c376c215015ef29454aab44c8ea564b1a221dc8a (dostęp: 22.07.2021).

Sprengel M., Znaczenie politycznych i gospodarczych relacji Australii ₹. Japoniq i Chinami w latach 1970_ 2000, „Krakowskie Studia Międzynarodowe” 2009, t. 6, nr 1.

The 14 disputes of China to Australia, 23.11.2020, https://www.voltairenet.org/article211799.html (dostęp: 22.07.2021). 
Trade and Investment, Australian Government, Department of Foreign Affairs and Trade, https://www.dfat.gov.au/trade/trade-and-investment (dostęp: 22.07.2021).

\#Tydzieńw Azji: Ponad 200-procentowe cla. Eksport z. Australii dalej pod presja Pekinu, Instytut Boyma, 6.04.2021, https://www.wnp.pl/rynki-zagraniczne/tydzienwazji-ponad-200-procentowe-cla-eksport-z-australii-dalej-pod-presja-pekinu,460615.html (dostęp: 22.07.2021).

Wnukowski D., Komentary PISM: Porozumienie transpacyficzne bez. USA, komentarz nr 17/2018, https://pism.pl/publikacje/Komentarz_PISM_Porozumienie_transpacyficzne_bez_USA (dostęp: 22.07.2021).

Wnukowski D., Podpisanie RCEP - najwięeszej na świecie umowy o wolnym handlu, komentarz nr 84, https://pism.pl/publikacje/Podpisanie_RCEP__najwiekszej_na_swiecie_umowy_o_wolnym_handlu (dostęp: 22.07.2021).

Wolska A., Chiny wstraymaja import ₹. Australii wart nawet 6 mld dolarów?, 6.11.2020, https://www.euractiv.pl/section/bezpieczenstwo-i-obrona/news/chiny-wstrzymaja-import-z-australii-wart-nawet-6-mld-dolarow/ (dostęp: 22.07.2021).

Zdziech D., QUAD-Australia. Nowe otwarcie, „Krakowskie Studia Międzynarodowe” 2018, nr 4.

Żołądkiewicz K., Wszechstronne Regionalne Partnerstwo Ekonomiczne (RCEP) jako prazykład nowego trendu w regionalizmie, „Finanse, Rynki Finansowe, Ubezpieczenia” 2016, nr 3.

Żukrowska K., Chiny: potencjat (gospodarcsy), polityczny i militarny) jako instrument kształtowania nowego układu międrynarodowego, „Krakowskie Studia Międzynarodowe” 2018, nr 1.

\section{SUMMARY}

\section{AUSTRALIAN-CHINESE GOODS TRADE IN THE CONTEXT OF THE RCEP AND THE TRADE WAR - DIAGNOSIS AND DEVELOPMENT PROSPECTS}

The aim of this article is to analyze changes in merchandise bilateral trade relationships between Australia and China in the years of 2000-2020. Particular attention was paid to the importance of the Regional Comprehensive Economic Partnership and the trade war in response to Austalia's call for an international inquiry into China's handling of the coronavirus when the pandemic had become an international issue. The main purpose of this article is to diagnose and evaluate Australian-Chinese relations. The thesis was formulated as follows: the political conflict between China and Australia translates into mutual trade relations, the consequences of which are felt by both sides, but in the coming years China will still be Australia's most important trading partner. At the same time, Australia will be looking for new markets, and China will be looking for new suppliers. 